\title{
Circular business models: A review
}

\section{Geissdoerfer, Martin; Pieroni, Marina P.P.; Pigosso, Daniela C. A.; Soufani, Khaled}

\section{Published in:}

Journal of cleaner production

Link to article, DOI:

10.1016/j.jclepro.2020.123741

Publication date:

2020

Document Version

Publisher's PDF, also known as Version of record

Link back to DTU Orbit

Citation (APA):

Geissdoerfer, M., Pieroni, M. P. P., Pigosso, D. C. A., \& Soufani, K. (2020). Circular business models: A review. Journal of cleaner production, 277, [123741]. https://doi.org/10.1016/j.jclepro.2020.123741

\section{General rights}

Copyright and moral rights for the publications made accessible in the public portal are retained by the authors and/or other copyright owners and it is a condition of accessing publications that users recognise and abide by the legal requirements associated with these rights.

- Users may download and print one copy of any publication from the public portal for the purpose of private study or research.

- You may not further distribute the material or use it for any profit-making activity or commercial gain

- You may freely distribute the URL identifying the publication in the public portal

If you believe that this document breaches copyright please contact us providing details, and we will remove access to the work immediately and investigate your claim 
Review

\title{
Circular business models: A review
}

\author{
Martin Geissdoerfer ${ }^{\text {a, }}{ }^{*}$, Marina P.P. Pieroni ${ }^{b}$, Daniela C.A. Pigosso ${ }^{b}$, Khaled Soufani ${ }^{\text {a }}$ \\ ${ }^{a}$ University of Cambridge, Circular Economy Centre, Judge Business School, Trumpington St, Cambridge, CB2 1AG, United Kingdom \\ ${ }^{\mathrm{b}}$ Technical University of Denmark (DTU), Department of Mechanical Engineering, Nils Koppels Alle 404 / Room 231, DK- 2800, Kgs, Lyngby, Denmark
}

\section{A R T I C L E I N F O}

\section{Article history:}

Received 9 November 2019

Received in revised form 30 July 2020

Accepted 11 August 2020

Available online 22 August 2020

Handling editor M.T. Moreira

\section{Keywords:}

Circular business model

Business model innovation

Sustainable business model

Circular economy

Review

\begin{abstract}
A B S T R A C T
The Circular Economy is gaining traction in academia, industry, and policy making as an alternative model that minimises resource depletion, waste, and emissions. To implement the concept on the organisational level, business models are an important leverage. A body of literature has emerged investigating the notion of circular business model and circular business model innovation, however, there is considerable lack of clarity about their theoretical conceptualisation. To address this and systematise the state-of-the-art of the nascent field of circular business models and circular business model innovation, we have reviewed this literature, employing systematic database searches and crossreference snowballing. Our contributions to conceptual clarity are: (1) an overview of the history of the concepts of circular business model and circular business model innovation, (2) an overview and synthesis of definitions of circular business model and circular business model innovation, and (3) an overview and synthesis of conceptual frameworks for circular business model and circular business model innovation.
\end{abstract}

๑) 2020 The Author(s). Published by Elsevier Ltd. This is an open access article under the CC BY license (http://creativecommons.org/licenses/by/4.0/).

\section{Contents}

1. Introduction ....

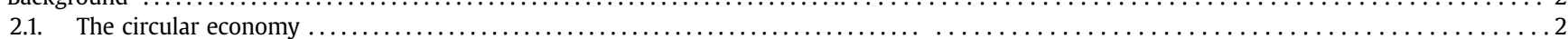

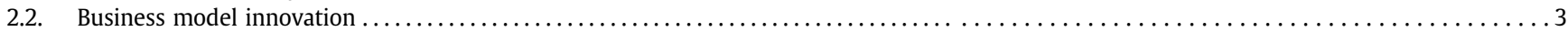

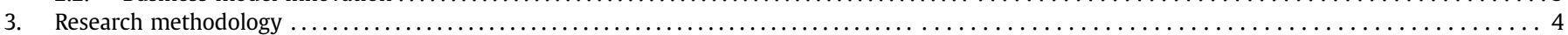

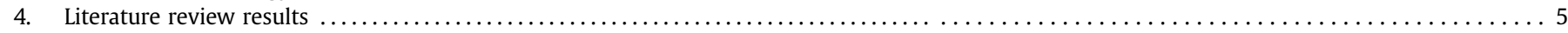

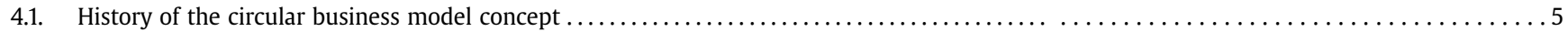

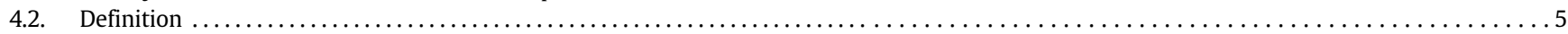

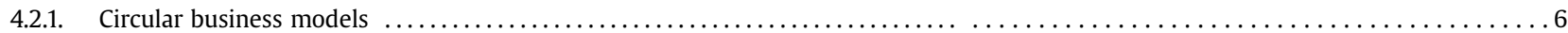

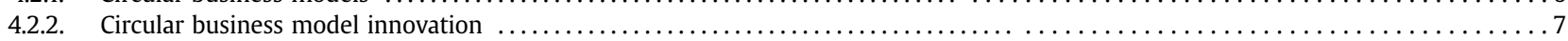

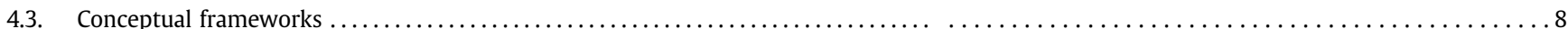

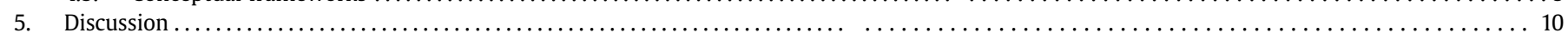

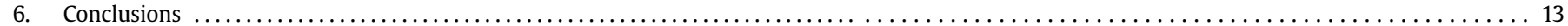

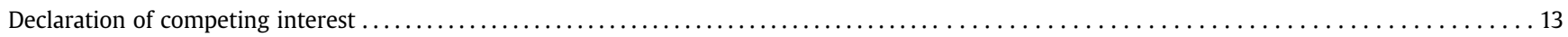

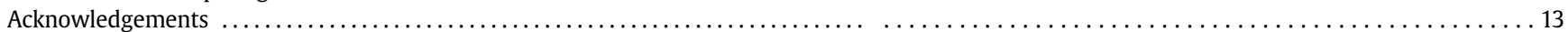

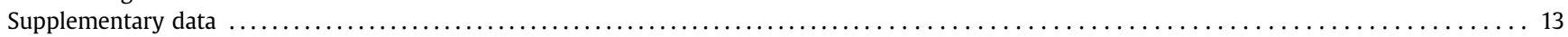

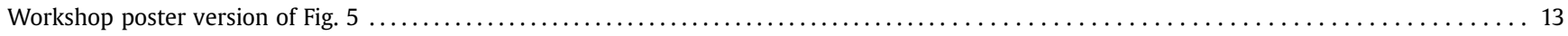

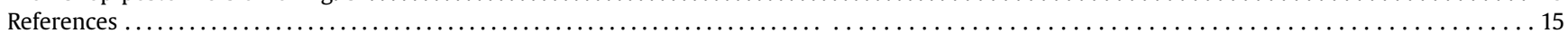

* Corresponding author.

E-mail addresses: ml733@cam.ac.uk (M. Geissdoerfer), mdpp@mek.dtu.dk (M.P.P. Pieroni), danpi@mek.dtu.dk (D.C.A. Pigosso), k.soufani@jbs.cam.ac.uk (K. Soufani).

\section{Introduction}

The notion of a circular economy has gained prominence on the agendas of policymakers around the world (Brennan et al., 2015), resulting, for example, in the European Circular Economy package 
(European Commission, 2015) and the Chinese Circular Economy Promotion Law (Lieder and Rashid, 2016) and attracted considerable attention from the private sector (Esposito et al., 2016), which lead to a range of initiatives by major companies, such as Google, Renault and Unilever (Bocken et al., 2017). The concept has also become an important field of academic research with a considerable increase in articles and journals that cover this topic in the last decade (Geissdoerfer et al., 2017).

For industrial practitioners, business model innovation is seen as key leverage to implement the circular economy on the organisational level, as it allows for a systemic shift in the core logic of businesses and the alignment of incentives of different stakeholder groups (Rashid et al., 2013; Schulte, 2013). A circular economy system requires the design and implementation of business models that are based on using as little resources for as long as possible, while extracting as much value as possible in the process. Organisations that are willing to adopt the circular economy model need to implement new types of business models by rethinking value propositions and developing value chains that offer feasible cost efficiency, production effectiveness, and business performance (Rashid et al., 2013; Schulte, 2013). As a result, research about business model innovation related to the circular economy has received increasing attention in the past five years (Diaz Lopez et al., 2019).

Despite the importance of the circular business model notion, there is considerable lack of clarity about its theoretical conceptualisation and position in economic and operations literature. Recent research calls for the establishment of consensual foundations (e.g. definitions) and a shared conceptual framework to support practitioners with the design and implementation of a circular business models and also the execution of a circular business model innovation (Pieroni et al., 2019a; Rosa et al., 2019). In particular, a conceptual framework is required to clarify which specific practices for value proposition, value capture, value delivery (i.e. customer involvement) and value creation (i.e. supply chain management) can enable different circular business models (Rosa et al., 2019). To the best of our knowledge, existing reviews in the field barely address the conceptualisation of circular business models and circular business model innovation, as most of them focus on the overall conceptualisation of a circular economy itself (more details in Table 1 of section 2.1). Moreover, existing reviews about circular business models or circular business model innovation focus on specific approaches or tools (Bocken et al., 2019; Pieroni et al., 2019a; Rosa et al., 2019), but not in their theoretical conceptualisation.

To address this gap, this research aims to systematise the stateof-the-art of circular business models and circular business model innovation to increase conceptual clarity and the efficacy of the concepts' use in theory and practice. Therefore, we conducted a literature review of the circular business models and business model innovation concepts, employing systematic string-based database searches and cross-reference snowballing.

As a result, we identified definitions of key underlying concepts around circular business model and circular business model innovation and proposed a synthesised definition for both concepts. Additionally, we proposed a conceptual framework to advance the discussions of the multiple boundaries of analysis adopted for business model innovation (i.e. organisational, inter-organisational, ecosystem), which is intensified within the circular economy scope. Lastly, we consolidated a conceptual framework explaining how different circular business model strategies (i.e. close, slow, intensify, dematerialise) affect the elements or components of business models' structures (i.e. value proposition, value creation \& delivery, and value capture).

This paper is structured in six sections: After this introduction, section 2 reviews the concepts of circular economy and business model innovation underlying this research. Section 3 explains the research methodology, section 4 presents the results of the literature review, and section 5 provides a discussion about the results. The paper concludes with final remarks in section 6 .

For better readability, we avoid abbreviations, but will use CE for circular economy, BM for business model, BMI for business model innovation, CBM for circular business model, CBMI for circular business model innovation, SBM for sustainable business model, and SBMI for sustainable business model innovation where appropriate, for example in tables and figures with space constraints. Terms that are identical in substance, such as circular business models and business models for circular economy are used synonymously.

\section{Background}

The circular business model notion is based on two underlying concepts: the circular economy and business model innovation. This section shortly introduces both topics.

\subsection{The circular economy}

The concept of the circular economy is influenced by Boulding's (1966) work. He argued that for the economy and the environment to coexist in equilibrium, the Earth should be seen as a desirable closed-loop system (or closed spaceship economy in his words) with limited assimilative capacity. Stahel and Reday (1976) also introduced certain features of a circular economy, with a focus on industrial economics. They conceptualised a loop economy to describe industrial strategies for waste prevention, regional job creation, resource efficiency, and dematerialisation of the industrial economy. Stahel (1982) also emphasised that selling utilisation

Table 1

Reviews about circular economy.

\begin{tabular}{|c|c|}
\hline Publication & Focus \\
\hline Andersen (2007) & Introduction to fundamental principles and approaches in environmental economics relevant for CE. \\
\hline Su et al. (2013) & Analysis of CE concept and research in China. \\
\hline Ghisellini et al. (2016) & Analysis of CE literature and exploration of its origins, basic principles, advantages, disadvantages, modelling and implementation. \\
\hline Lieder and Rashid (2016) & Analysis of CE literature and exploration of different ideas relevant to CE and their recurrence in the context of manufacturing companies. \\
\hline Sauvé et al. (2016) & Comparison of CE, environmental sciences and sustainable development concepts. \\
\hline Geissdoerfer et al. (2017) & Comparison of CE and sustainability concepts. \\
\hline Blomsma and Brennan (2017) & Analysis of the emergence and evolution of the CE concept. \\
\hline Murray et al. (2017) & Exploration of the CE concept based on an interdisciplinary perspective. \\
\hline Kirchher et al. (2017) & Conceptualisation of CE through review of 114 CE definitions. \\
\hline Merli et al. (2018) & Analysis of the CE phenomenon and characterisation of the literature. \\
\hline Turkeli etv al. (2018) & Analysis of the evolution of CE research in European Union and China. \\
\hline Homrich et al. (2018) & Analysis of trends and gaps of the CE literature. \\
\hline
\end{tabular}


instead of ownership of goods is a relevant business model for a loop economy, allowing industries to profit while reducing or minimising costs and risks associated with waste.

The contemporary understanding of a circular economy system, introduced by Pearce and Turner (1989), incorporates different features and contributions from a variety of concepts that share the idea of closed loops, such as: industrial ecology (Graedel and Allenby, 1995), cradle-to-cradle (McDonough and Braungart, 2002), laws of ecology (Commoner, 1971), looped and performance economy (Stahel, 2010), regenerative design (Lyle, 1994), biomimicry (Benyus, 2002), the blue economy (Pauli, 2010) and life cycle management and engineering (Niero et al., 2017; Hauschild et al., 2005). The Important roles in framing and popularising the concept in its contemporary curated form was played by Ellen MacArthur Foundation supported by the consultancy McKinsey, who co-authored a range of seminal and influential reports on the topic (EMF, 2012, 2014, 2015).

Since 2013, the circular economy concept has received increasing attention in academia with a range of reviews on the topic (Table 1) and a special issue in California Management Review (2018, Volume 60, Issue 3).

This resulted in a range of different definitions of the concept. For example, Yuan et al. (2008) state that "the core of [circular economy] is the circular (closed) flow of materials and the use of raw materials and energy through multiple phases". Webster (2015) adds that "a circular economy is one that is restorative by design, and which aims to keep products, components and materials at their highest utility and value, at all times". Bocken et al. (2016, p.309) categorise the characteristics of circular economy by defining it as "design and business model strategies [that are] slowing, closing, and narrowing resource loops".

Kirchherr et al. (2017) reviewed 114 definitions for the circular economy and, based on their analysis, proposed a new definition: "A circular economy describes an economic system that is based on business models, which replaces the 'end-of-life' concept with reducing, alternatively reusing, recycling and recovering materials in production/distribution and consumption processes, thus operating at the micro level (products, companies, consumers), meso level (eco-industrial parks) and macro level (city, region, nation and beyond), with the aim to accomplish sustainable development, which implies creating environmental quality, economic prosperity and social equity, to the benefit of current and future generations".

However, a previous review of circular economy literature (Geissdoerfer et al., 2017) reveals a range of shortcomings for this definition. For example, the definition simplifies the term 'end-oflife' to 'disposal', disregarding the more common, broader interpretation adopted by product development theory, has a reduced focus on other lifecycle stages, specifies a three-tier level system that simply translates into 'all levels', and puts an undue focus on sustainability aspects not always included in the circular economy concept.

Therefore, we have revisited the 114 definitions and adapted an older definition by the authors (Geissdoerfer et al., 2017, p. 759). For this research, we will define circular economy as an economic system in which resource input and waste, emission, and energy leakages are minimised by cycling, extending, intensifying, and dematerialising material and energy loops. This can be achieved through digitalisation, servitisation, sharing solutions, long-lasting product design, maintenance, repair, reuse, remanufacturing, refurbishing, and recycling. We have illustrated the definition in Fig. 1.

Since a completely closed-loop system is not theoretically possible (Zotti and Bigano, 2019; Skene, 2018), our understanding of a circular economy refers to a dynamic perspective - 'going circular' rather than a static perspective of a (impossible) fully circular system in which no leakage of materials and energy occurs.

\subsection{Business model innovation}

The business model concept gained popularity and started evolving into its modern interpretation during the dot.com boom of the 1990's (Wirtz et al., 2010), when innovative revenue mechanisms were introduced. In this context, the business model concept was originally used to communicate complex business ideas to potential investors within a short time frame (Zott et al., 2011).

From this basic function, the business model concept evolved into both a (i) tool for systemic analysis, planning, and communication (Knyphausen-Aufseß and Meinhardt, 2002; Doleski, 2015), as well as a (ii) strategic asset for competitive advantage and firm performance (Afuah, 2004; Casadesus-Masanell and Ricart, 2010; Chesbrough, 2007; Hamel, 2000; Magretta, 2002).

The capability to quickly and successfully innovate and introduce business models can create an important competitive advantage for organisations, due to falling returns on technology (Chesbrough, 2007), growing complexity (Jensen, 1997), and falling cost of capital (Mankins et al., 2017). This might be amplified through the increasing disruption of digital transformation (Christensen and Overdorf, 2000; Berman, 2012; Andal-Ancion et al., 2004), as indicated by the considerable market valuation of relatively new tech conglomerates with innovative digital BMs (Parker et al., 2017).

Business model innovation capabilities are not only potentially leading to yield higher returns than product or process innovations (Lindgardt and Reeves, 2015; Chesbrough, 2007), but might prove to become a 'renewable' competitive advantage. Business model innovation capabilities can trigger a dynamic sustainable competitive advantage for companies (Casadesus-Masanell and Zhu, 2013; Slocum et al., 1994; Afuah, 2004; Magretta, 2002; Chesbrough, 2007), which further increases their importance for organisational strategy (Richardson, 2008; Teece, 2010; Casadesus-Masanell and Ricart, 2010).

Business model innovation is also critical for organisations to meet their social and environmental ambitions by leveraging environmentally, socially, and economically effective technologies and solutions (Boons and Lüdeke-Freund, 2013; Geissdoerfer et al., 2016; Rashid et al., 2013). Companies engaged in sustainable business model innovation can improve their financial, social, and environmental performance (Nidumolu et al., 2009; Porter and Kramer, 2011) and improve resilience and exposure to risks from their environment (Evans et al., 2009; Freeman, 1984).

The business model innovation concept has also received increasing attention in academia with a range of reviews on the topic, like Bieger and Reinhold (2011), George and Bock (2011), Zott et al., (2011), Massa et al. (2017), Schallmo (2013), Spieth et al. (2014), Wirtz et al. (2016), Foss and Saebi (2017), and an extensive special issue in the Long Range Planning journal (2010, Volume 43 Issue 2-3).

This resulted in a range of different definitions of the concept, as exemplified in Table 2.

For this research we use an earlier definition by the authors, based on a comprehensive review of the field: business model innovation is "the conceptualisation and implementation of new business models that can comprise the development of entirely new business models, the diversification into additional business models, the acquisition of new business models, or the transformation from one business model to another. The transformation can affect the entire BM or individual or a combination of its value proposition, value creation and deliver, and value capture elements, the interrelations between the elements, and the value network." (Geissdoerfer et al., 2018b). 


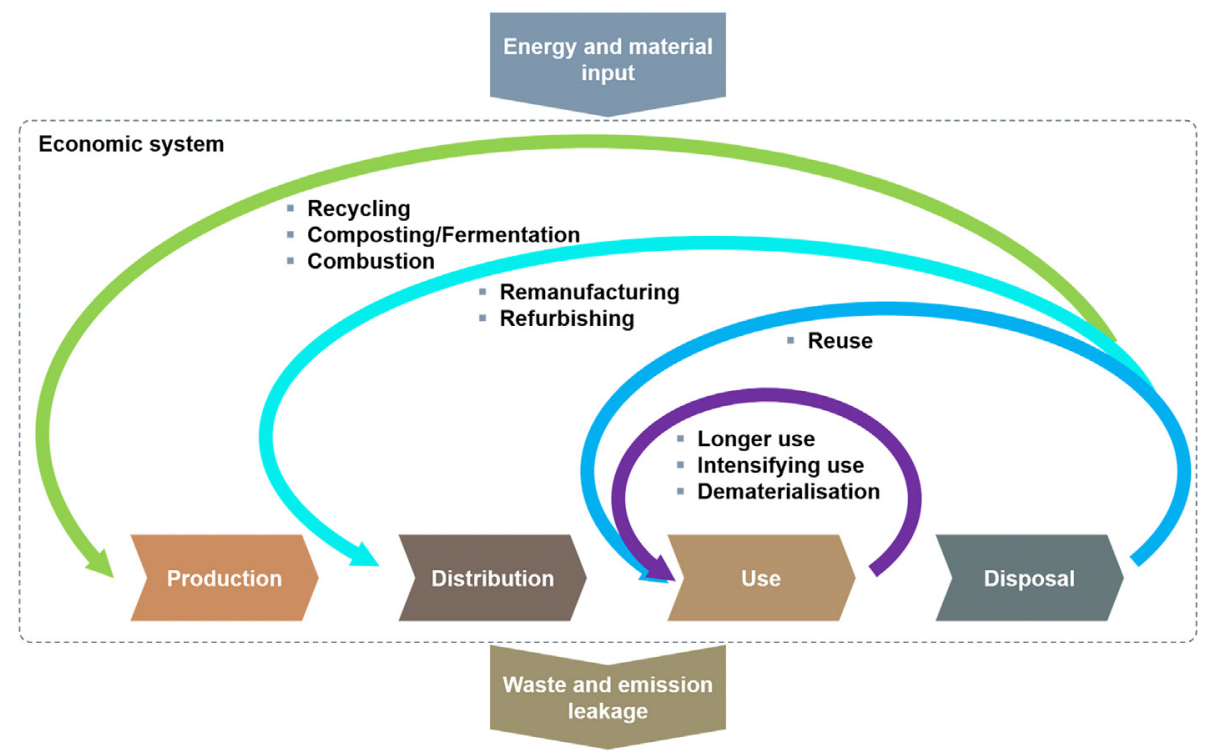

Fig. 1. The circular economy.

Table 2

Selected business model innovation definitions.

\begin{tabular}{|c|c|}
\hline Publication & Definition \\
\hline $\begin{array}{l}\text { Mitchell and Coles } \\
\text { (2004) }\end{array}$ & $\begin{array}{l}\text { "business model replacements that provide product or service offerings to customers and end users that were not previously available. [And] refer } \\
\text { to the process of developing these novel replacements as business model innovation" (p. 17) }\end{array}$ \\
\hline $\begin{array}{l}\text { Osterwalder et al. } \\
\text { (2005) }\end{array}$ & $\begin{array}{l}\text { "specifying a set of business model elements and building blocks, as well as their relationships to one another [...] a business model designer [...] } \\
\text { can experiment with these blocks and create completely new business models" (p. 24) }\end{array}$ \\
\hline Chesbrough (2007) & "advance [the] business model [...] from very basic (and not very valuable) models to far more advanced (and more valuable) models" (p.15) \\
\hline Johnson (2010) & $\begin{array}{l}\text { "the ability to innovate something more core than the core, to innovate the very theory of the business itself. I call that process business model } \\
\text { innovation" (p. 13) [...] "business model innovation is an iterative journey" (p. 114) }\end{array}$ \\
\hline
\end{tabular}

\section{Research methodology}

To contribute to reducing the conceptual lack of clarity in the circular business model innovation literature by means of knowledge systematisation, this research is based on a systematic literature review organised in a three-step protocol: data search, data analysis and report (de Almeida Biolchini et al., 2007).

Data search encompassed two steps. First, the search string TITLE-ABS-KEY ("circular*” AND "business model*“) was applied to search for journal articles and reviews in English on the Elsevier Scopus database. Abstracts of identified publications (207 as of May 2019) were scanned to define an initial sample of relevant literature composed of 30 articles for full text reading according to two selection criteria (see Supplementary Materials for details):

i. Circular business model or circular business model innovation are explicitly addressed as one of the main topics of study;

ii. Conceptual contributions that explicitly address items on the scope of this study (i.e. reviews, definitions, schools of thought/ origins, characteristics/types/conceptual frameworks).

As a second step, a backward snowballing approach (Wohlin, 2014) was performed to capture established and also conceptual knowledge falling outside of the database searches or originated prior to the establishment of the contemporary concept of circular economy. References of the initial selected sample were screened and articles were selected according to their relevance (based on their title and content) and following the same selection criteria described above. Abstracts of the identified additional publications were scanned also followed the same selection criteria described above to determine whether the publications were relevant to be included into the sample. The same snowballing procedure was applied to the added publications, which was continued until no further relevant publications were identified. Thus, 21 publications identified through snowballing were added to the sample, which increased the final sample to 51 publications.

The data analysis part employed content analysis and coding techniques (Dresch et al., 2015) to categorise publications according to the topics of interest for this literature review:

i) History of the circular business model and circular business model innovation concepts $(\mathrm{H})$ : divided into seven subgroups representing correlated research areas (i.e. business model innovation; performance economy; cradle-to-cradle; sustainable business model innovation; circular business model innovation; product-service systems; and digitalisation) that emerged throughout the analysis.

ii) Definitions of the concepts (D): divided into two sub-groups - i.e. circular business model and circular business model innovation definitions;

iii) Conceptual frameworks for circular business models (F): divided into three sub-groups representing types of conceptual frameworks (i.e., reference models; requirements; and classifications) based on a previous publication (Pieroni et al., 2019a) and explained in section 4.3.

Data reporting consisted of integrating, synthesising and compiling analyses in the following reported results (section 4). 


\section{Literature review results}

This section introduces the review's results in four sub-sections. After an overview of the history of circular business model innovation sub-stream (section 4.1), definitions of circular business model and circular business model innovation (section 4.2) and conceptual frameworks (section 4.3) are presented.

\subsection{History of the circular business model concept}

The concept of circular business model emerged considerably more recently than the circular economy literature as a whole. As illustrated in Fig. 2, the term first appeared in 2006 in an article by Schwager and Moser (2006) that explored individual business model types for circular value creation.

The circular business model concept re-emerged seven years later, coinciding with the broader dissemination of the circular economy notion by the Ellen MacArthur Foundation and the World Economic Forum (WEF, 2014; EMF, 2012). Rashid et al. (2013) pointed to business model as an answer to incentivise alignment issues that explain the slow uptake of rapidly advancing technologies that would enable recycling a broad range of products and materials. Similarly, Schulte (2013) advocated the role of business models for the "circular economy to flourish in the long run". According to him, businesses should interpret and approach circular economy as a new way of making profit, instead of a tool to increase companies' resilience by protecting against raw materials' prices volatility.

Since 2015, publications have grown exponentially, with 13 articles in 2016, 38 in 2017, and 88 in 2018. This rise in interest is also confirmed by parallel reviews on the topic (Diaz Lopez et al., 2019; Pieroni et al., 2019a; Bocken et al., 2019; Rosa et al., 2019) and could be associated with the increasing availability of dedicated research funding (Pieroni et al., 2019a) and high citation counts in this relatively small time scale. For instance, the three most cited papers in our sample, Geissdoerfer et al., (2017), Murray et al., (2017) and Bocken et al. (2016) are all published in the last three years and have already received 235,160 , and 145 citations respectively.

Despite the recent history of the circular business model concept as an independent stream of research (Nußholz, 2017), some ideas related to the concept were already being addressed in parallel fields for a longer period. Cradle-to-cradle (McDonough and
Braungart, 2002) and Performance Economy (Stahel, 2010) already addressed the notion of circular business models even before or simultaneously to the emergence of the modern version of the business model concept (as considered in this study) (Wirtz et al., 2016) or the establishment of business model innovation as a field of research (Foss and Saebi, 2017). Likewise, the sub-field of sustainable business model innovation, which emerged in the late 2000's (Birkin et al., 2009; Stubbs and Cocklin, 2008; LüdekeFreund and Dembek, 2017), considers circular business models (e.g. create value from waste) as one archetype or sub-category of sustainable business models (Bocken et al., 2014), with a narrower primary focus on environmental and economic outcomes (Geissdoerfer et al., 2018a).

Another co-related field is product-service-systems (PSS), which started around 1990's with an environmental approach (Tukker, 2004; Mont, 2002), but after 2010 gained a more economic focus (Haase et al., 2017), coincidently with the dissemination of the overlapping servitisation theory (Baines et al., 2009; Rabetino et al., 2018). Recently, the focus on the environmental perspective of PSS seems to be approached more frequently with some dedicated reviews (Tukker, 2015; Annarelli et al., 2016) and CE-related research (Yang et al., 2018; Pieroni et al., 2019b). This is probably propelled by the boost of CE-oriented research. Reviews about business model innovation in the context of PSS have also appeared as in Reim et al. (2015). From the environmental perspective, PSS-related business model innovation could be considered a 'narrower' approach than CE-related business model innovation, i.e., PSSrelated business models could represent types or a sub-category of circular business models.

Lastly, modern parallel theories, such as digitalisation, have also been studied in relation to business model innovation and productservice systems, and can work as an enabler of business models' transformation towards enhanced circularity, related to predictive maintenance and product tracking (Parida et al., 2019; Bressanelli et al., 2018).

\subsection{Definition}

This section analyses how the concepts of circular business models and circular business model innovation are defined in the literature and synthetises a unified definition based on this analysis.

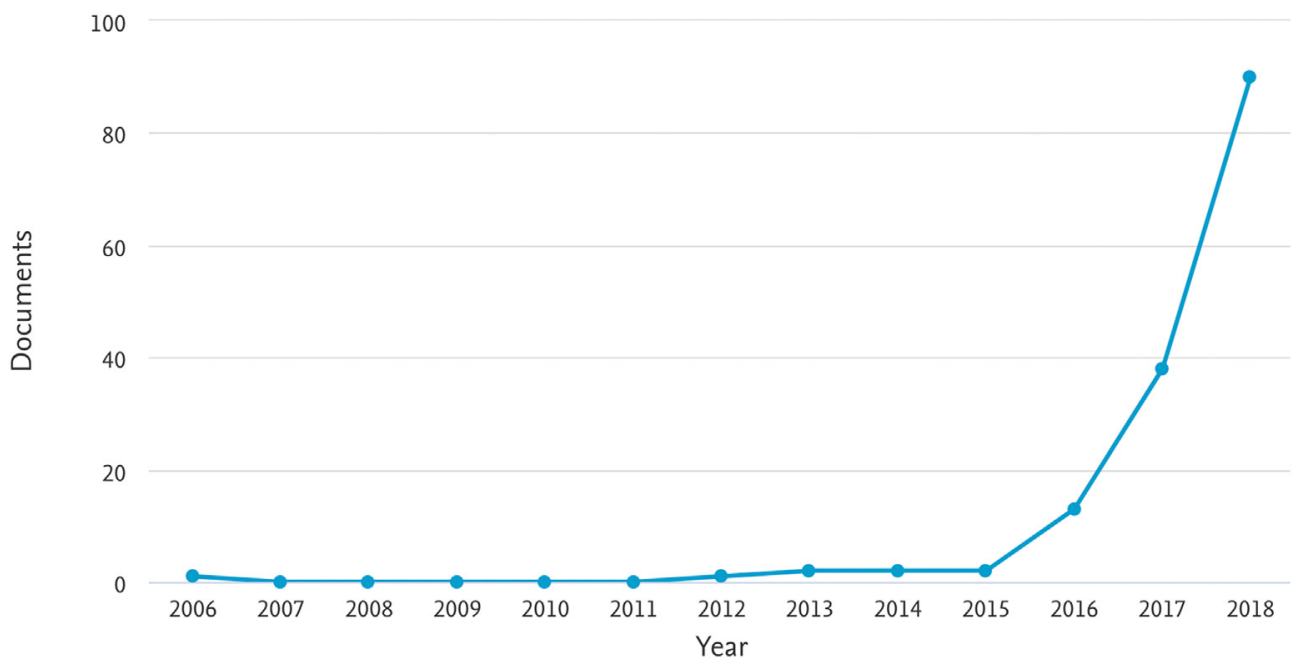

Fig. 2. Development of circular business model journal articles and reviews published over time. Source: Elsevier Scopus database. 
Table 3

Selected circular business model definitions.

\begin{tabular}{|c|c|c|}
\hline Publication & Definition & Comments \\
\hline Mentink (2014) & $\begin{array}{l}\text { "A circular business model is the rationale of how an organisation } \\
\text { creates, delivers and captures value with and within closed material } \\
\text { loops" (p.24) }\end{array}$ & $\begin{array}{l}\text { A widely cited Master's thesis, simply combines Osterwalder and } \\
\text { Pigneur's (2010, p.14) BM definition with a simplistic CE definition. }\end{array}$ \\
\hline Roos (2014) & $\begin{array}{l}\text { "A circular value chain business model (or green business model) is one } \\
\text { in which all intermediary outputs that have no further use in the value } \\
\text { creating activities of the firms are monetised in the form of either cost } \\
\text { reductions or revenue streams" (p. 257) }\end{array}$ & $\begin{array}{l}\text { Focuses on selling waste. It remains unclear how the waste that is not } \\
\text { used in value creation activities can reduce costs. }\end{array}$ \\
\hline Bocken et al. (2016) & $\begin{array}{l}\text { "business model strategies suited for the move to a CE [based on the] } \\
\text { taxonomy of slowing, closing, and narrowing resource loops" (p. 317) }\end{array}$ & Not explicit referred to as a definition by the authors. \\
\hline $\begin{array}{l}\text { Den Hollander and } \\
\text { Bakker (2016) }\end{array}$ & $\begin{array}{l}\text { "A circular business model describes how an organisation creates, } \\
\text { delivers, and captures value in a circular economic system, whereby the } \\
\text { business rationale needs to be designed in such a way that it prevents, } \\
\text { postpones or reverses obsolescence, minimises leakage and favours the } \\
\text { use of 'resources' over the use of resources in the process of creating, } \\
\text { delivering and capturing value" (p. 2) }\end{array}$ & $\begin{array}{l}\text { The authors emphasise the role of product obsolescence and include } \\
\text { Richardson's (2008) value logic twice in one sentence, illustrating its } \\
\text { central role in the conceptualisation of CBMs. }\end{array}$ \\
\hline $\begin{array}{l}\text { Linder and Williander } \\
\qquad(2017)\end{array}$ & $\begin{array}{l}\text { "We define a circular business model (CBM) as a business model in } \\
\text { which the conceptual logic for value creation is based on utilising } \\
\text { economic value retained in products after use in the production of new } \\
\text { offerings. Thus, a circular business model implies a return flow to the } \\
\text { producer from users, though there can be intermediaries between the } \\
\text { two parties. The term circular business model therefore overlaps with } \\
\text { the concept of closed-loop supply chains, and always involves recycling, } \\
\text { remanufacturing, reuse or one of their sibling activities (e.g. } \\
\text { refurbishment, renovation, repair)" (p. 183) }\end{array}$ & $\begin{array}{l}\text { Only addresses the "closing resource loops" strategy. Assumes that a } \\
\text { CBM "always involves" re-X strategies. }\end{array}$ \\
\hline Nußholz (2017) & $\begin{array}{l}\text { "A circular business model is how a company creates, captures, and } \\
\text { delivers value with the value creation logic designed to improve } \\
\text { resource efficiency through contributing to extending useful life of } \\
\text { products and parts (e.g., through long-life design, repair and } \\
\text { remanufacturing) and closing material loops" (p. 12) }\end{array}$ & $\begin{array}{l}\text { Builds on Den Hollander and Bakker (2016) and Bocken et al. (2016) } \\
\text { definitions. Mixes closing and slowing resource loops. }\end{array}$ \\
\hline Urbinati et al. (2017) & $\begin{array}{l}\text { "i.e. different modes of adoption of CE by [...] single firms }[\ldots] \text { as they } \\
\text { adopt any of the circular practices (e.g., redistribution and reuse, } \\
\text { remanufacturing or recycling of products) in their internal activities" (p. } \\
487 \text { ) }\end{array}$ & $\begin{array}{l}\text { Uses single firm as unit of analysis. It remains unclear if the authors only } \\
\text { address the "closing resource loops" strategy. }\end{array}$ \\
\hline $\begin{array}{l}\text { Geissdoerfer et al. } \\
\quad(2018 a)\end{array}$ & $\begin{array}{l}\text { "CBM can be defined as SBMs [sustainable business models] - which are } \\
\text { business models that aim at solutions for sustainable development by } \\
\text { creating additional monetary and nonmonetary value by the pro-active } \\
\text { management of a multiple stakeholders and incorporate a long-term } \\
\text { perspective - that are specifically aiming at solutions for the CE [i.e. } \\
\text { closing, narrowing, slowing, intensifying, and dematerialising resource } \\
\text { loops] through a circular value chain and stakeholder incentive } \\
\text { alignment" (p. 713f) }\end{array}$ & $\begin{array}{l}\text { Earlier definition by the authors. Assumes that CBMs are a subcategory of } \\
\text { SBMs. } \\
\text {. }\end{array}$ \\
\hline Lahti et al. (2018) & $\begin{array}{l}\text { "we propose a circular business model definition to explain how an } \\
\text { established firm uses innovations to create, deliver, and capture value } \\
\text { through the implementation of CE principles, whereby the business } \\
\text { rational are realigned between the network of actors/stakeholders to } \\
\text { meet environmental, social, and economic benefits" (p. 3) }\end{array}$ & $\begin{array}{l}\text { Focuses on use of innovations. Integrates stakeholder management and } \\
\text { assumes triple bottom line benefits or SBM characteristics. }\end{array}$ \\
\hline Manninen et al. (2018) & $\begin{array}{l}\text { "CE businesses aim to apply [the] CE principles [...] preserving and } \\
\text { enhancing natural capital, optimising yields from resources in use, and } \\
\text { fostering system effectiveness (minimising negative externalities) [...] to } \\
\text { their business models and shift from a linear business to more circular } \\
\text { one" (p. 414) }\end{array}$ & $\begin{array}{l}\text { Comprises “enhancing natural capital”, although it remains unclear what } \\
\text { this implies. }\end{array}$ \\
\hline $\begin{array}{l}\text { Oghazi and Mostaghel } \\
\text { (2018) }\end{array}$ & $\begin{array}{l}\text { "The rationale of how an organisation creates, delivers, and captures } \\
\text { value with slowing, closing, or narrowing flows of the resource loops" (p. } \\
\text { 3) }\end{array}$ & $\begin{array}{l}\text { Combines Bocken et al. (2016) with Richardson (2009) without referring } \\
\text { to either. }\end{array}$ \\
\hline $\begin{array}{l}\text { Lüdeke-Freund et al. } \\
\text { (2019) }\end{array}$ & $\begin{array}{l}\text { "as a means to redefine how companies create value while adhering to } \\
\text { CE principles" (p. } 37 \text { ) }\end{array}$ & $\begin{array}{l}\text { Synthesised from a range of other sources. It remains unclear what } \\
\text { "redefine" implies in this context. }\end{array}$ \\
\hline Ünal et al. (2019) & $\begin{array}{l}\text { "A circular business model represents a holistic system of co-evolving } \\
\text { managerial practices for collective value creation, delivery and capture, } \\
\text { which provide solutions for sustainable development" (p. 291) }\end{array}$ & $\begin{array}{l}\text { Focuses on managerial practices and assumes sustainable development } \\
\text { benefits or SBM characteristics. }\end{array}$ \\
\hline $\begin{array}{l}\text { Zucchella and Previtali } \\
\text { (Zucchella and } \\
\text { Previtali, 2019) }\end{array}$ & $\begin{array}{l}\text { "The business model's key role is to incorporate the CE principles into a } \\
\text { design or redesign of business activities and partnerships and to create a } \\
\text { cost and revenue structure, which is compatible both with sustainability } \\
\text { and with profitability" (p. 275) }\end{array}$ & $\begin{array}{l}\text { Assumes SBM characteristics. Might describe the purpose rather than the } \\
\text { concept itself. }\end{array}$ \\
\hline
\end{tabular}

\subsubsection{Circular business models}

There is a range of understandings of the circular business models or business models for the circular economy concept

\footnotetext{
1 Urbinati et al. (2017) refer to CE practices (e.g. recycling and reuse) and
} Manninen et al. (2018) refer to the related concept of Natural Capital instead. reflected in a diverse range of definitions, as exemplified in Table 3.

All but two ${ }^{1}$ of the reviewed definitions focus on value creation and roughly follow either the value logic framework of Richardson (2008), which envisions the value proposition, value creation and delivery, and value capture (e.g. Linder and Williander (2017), Nußholz (2017), and Lahti et al. (2018)), or the business model 


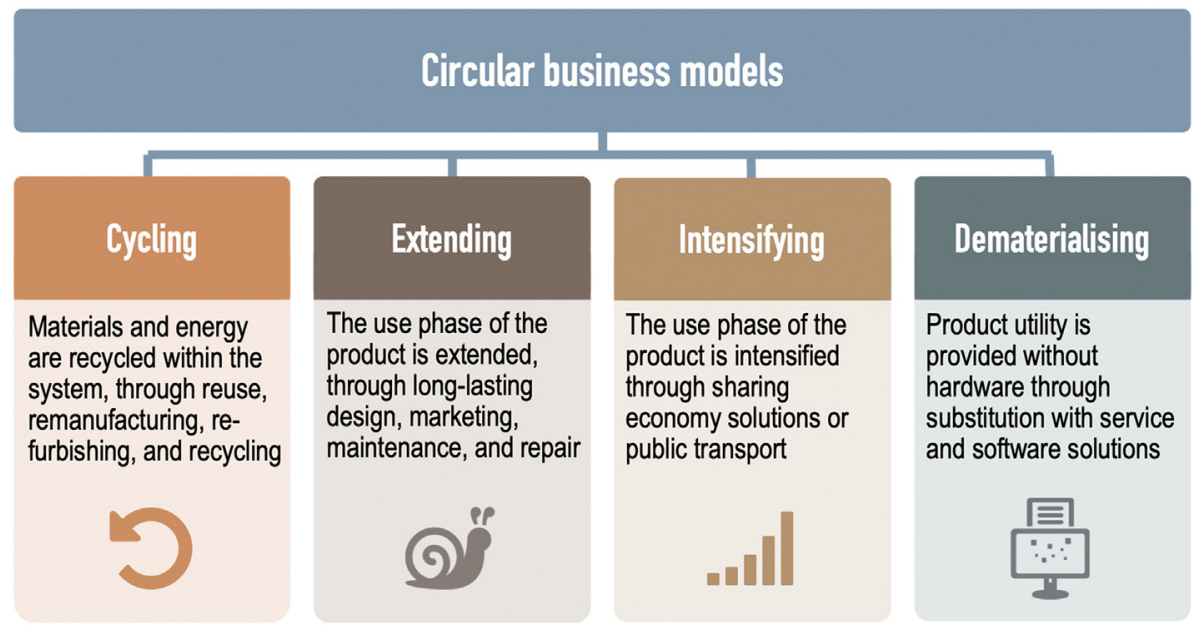

Fig. 3. Circular business model strategies, developed from Bocken et al. (2016) and Geissdoerfer et al. (2018a,b).

definition of Osterwalder and Pigneur (2010), which is based on that logic: "A business model describes the rationale of how an organisation creates, delivers, and captures value" (p.14).

This is then combined with circular economy principles (Manninen et al., 2018; Lüdeke-Freund et al., 2019; Zucchella and Previtali, 2019) or translated into circular business model strategies by Bocken et al. (2016), Geissdoerfer et al. (2018a,b), and Oghazi and Mostaghel (2018). These comprise recycling measures (closing), efficiency improvements (narrowing), use phase extensions (extending), a more intense use phase (intensifying), and the substitution of product utility by service and software solutions (dematerialising) (Geissdoerfer et al., 2018a,b)

However, while all of these strategies seem compliant with the circular economy as conceptualised for example by Webster (2015), we could not find any source that would justify a business model to qualify as 'circular' (Urbinati et al., 2017) or compliant with the circular economy concept solely based on the idea of narrowing loops (i.e. efficiency gains alone). Thus, this strategy seems to constitute more of an 'add-on' than a circular business model strategy in its own right.

Some authors highlight the relationship between circular and sustainable business models. Geissdoerfer et al. (2018a,b), Lahti et al. (2018), and Zucchella and Previtali (2019) assume sustainability aspects to be integral to the circular business model concept. This corresponds to a previous analysis carried by the authors that some but not all conceptualisations of circular business models focus on sustainability aspects (Pieroni et al., 2019a).

Based on this analysis of the literature, circular business models can be defined as business models that are cycling, extending, intensifying, and/or dematerialising material and energy loops to reduce the resource inputs into and the waste and emission leakage out of an organisational system. This comprises recycling measures (cycling), use phase extensions (extending), a more intense use phase (intensifying), and the substitution of products by service and software solutions (dematerialising).

The second half of the definition describes the four generic strategies for circular business models identified in the literature: (1) cycling; (2) extending; (3) intensifying; and (4) dematerialising, which we have illustrated in Fig. 3.

Cycling means that materials and energy are recycled within the system, through reuse, remanufacturing, refurbishing, and recycling. For example, decommissioned industrial robots can be reused in small and medium enterprises (SMEs), where their reduced purchasing cost enables a viable way to increase productivity through automatisation (Bi et al., 2015).

Extending resource loops implies that the use phase of the product is extended, through long-lasting and timeless design, marketing that encourages long use phases, maintenance, and repair. For example, Patek Philip builds upmarket mechanical watches that last for a long time and have a timeless design that has not changed considerably over the past decades. A marketing campaign supports this with the slogan "you never actually own [this watch]. You merely look after it for the next generation" (Naas, 2015).

Intensifying resource loops implies that the use phase of the product is intensified through solutions such as sharing economy (Hamari et al., 2016) or public transport (van de Velde, 1999). For example, car sharing can reduce idle times of cars and driven mileage per user significantly compared to a conventional ownership-based system (Prettenthaler and Steininger, 1999).

Dematerialising resource loops describes the provision of product utility without hardware through substitution with service and software solutions. For example, offering services or productservice systems instead of physical products to fulfil the same function for the user can reduce the number of produced products while enhancing the customer experience at the same time (Tan et al., 2010). Nevertheless, the product-service system has to be purposefully designed for resource decoupling, otherwise it could generate undesired or rebound effects that could trigger resource consumption increase (Pieroni et al., 2019b; Laumann et al., 2016; Kjaer et al., 2019).

"Organisational system" deliberately allows for different possible units of analysis, from the business unit to the ecosystem, depending on the descriptive or analytical task at hand. We have included a comprehensive discussion on the different units of analysis and the ongoing shift in the literature in the discussion (Section 5).

\subsubsection{Circular business model innovation}

There is a considerably smaller range of definitions for circular business model innovation or business model innovation for the circular economy. Most of these definitions are rather simplistic, such as a "shift from a linear to more circular business model." (Bocken et al., 2018, p. 80), "a shift from a linear business model to a circular business model" (Linder and Williander, 2017, p. 194) or "shifting from a linear to a circular production or business model" (Rizos et al., 2016, p. 3). 
A more comprehensive definition was provided by the authors in a previous paper. Here, based on the work by Bocken et al. (2016), Den Hollander, and Bakker (2016) we concluded that "CE-oriented business model innovation incorporates principles or practices from circular economy as guidelines for business model design. It aims at boosting resource efficiency and effectiveness (by narrowing or slowing energy and resource loops) and ultimately closing energy and resource flows by changing the way economic value and the interpretation of products are approached" (Pieroni et al., 2019a, p.201).

Some authors discuss the business model innovation and the interchangeably used business model transformation concept in the context of the circular economy (e.g. Bocken et al., 2016; Lewandowski, 2016; Linder and Williander, 2017) this seems to be consistent with how the circular business model concept is being based on the business model concept by nearly all authors in our sample.

We can therefore assume that the circular business model innovation concept is related to the business model innovation concept in the same way as circular business models are related to business models. This allows us to define the concept based on the previously synthesised definition of circular business models and the definition of business model innovation used in this research (see Section 1.2).

Consequently, circular business model innovation can be defined as the conceptualisation and implementation of circular business models, which comprises the creation of circular start-ups, the diversification into circular business models, the acquisition of circular business models, or the transformation of a business model into a circular one. This can affect the entire business model or one or more of its elements, the interrelations between the elements, and the value network.

The second half of the definition describes the four different types of circular business model innovation identified in the literature: (1) circular start-ups; (2) circular business model diversification; (3) circular business model transformation; and (4) circular business model acquisition, which we have illustrated in Fig. 4.

1) Circular business model transformation describes the modification of an existing business model. While the initial business model can be either both conventional or circular the resulting business model incorporates circular economy strategies.

2) Circular start-ups refer to the creation of new business models that incorporate circular economy strategies (i.e. cycling, extending, intensifying, and/or dematerialising resource loops) outside of an existing company - with their own brand, employees and resources - although they can be supported by nonindependent institutions, such as incubators or accelerators.

3) Circular business model diversification describes the development of new business models that incorporate circular economy strategies from within an existing organisation - using their resources and network. The current business model of the parent organisation stays in place and the new business models are either integrated into the organisation as new businesses or spun-off as subsidiaries. This also includes joint business model innovation projects with other organisations.

4) Circular business model acquisition describes merger and acquisition (M\&A) activities that target business models that incorporate circular economy strategies. It comprises the identification, acquisition, and integration of new circular business models. The extent of integration can vary.

Organisations can also combine different strategies, for example, support start-ups with an incubator programme and acquire successful participates for their business model portfolio,

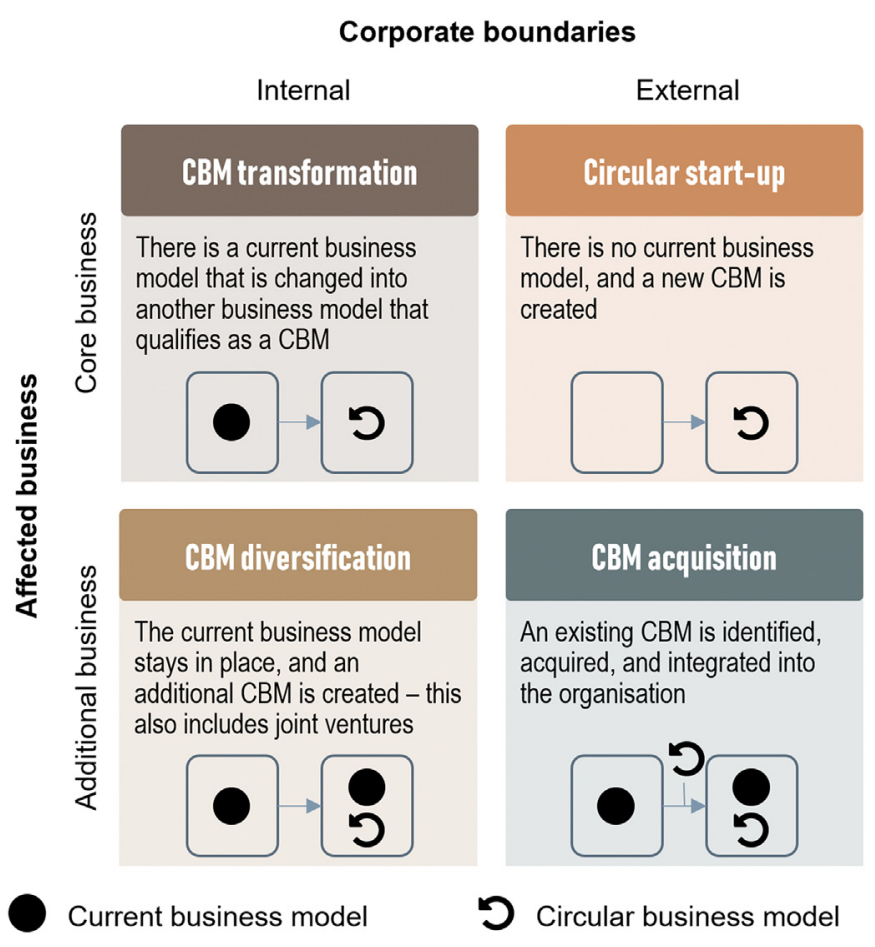

Fig. 4. Four types of circular business model innovation, developed from Geissdoerfer et al. (2018a,b).

while also diversifying their portfolio with the outputs of an internal business building unit. They could also divest from their core business towards this new portfolio or leverage acquisitions to introduce circular economy capabilities to transform their core business model (see also Geissdoerfer, 2019).

\subsection{Conceptual frameworks}

This section analyses the different conceptual frameworks for circular business models and circular business model innovation available in literature, and compares them with the objective of synthesising their differences and contributions.

The range of conceptual frameworks identified in the literature (detailed overview in Table 4) were organised in three different types of frameworks (based on the categories from Pieroni et al. (2019a)):

i) Reference models: tools or visual frameworks used to represent a circular business model in terms of its elements (e.g. revenue mechanism, customer segments);

ii) Requirements: generic descriptions of which elements are required to be altered in companies' existing business models to make them circular;

iii) Classifications: categorisations of potential structures or configurations of circular business models, i.e., how a circular business model should look like. This includes typologies, taxonomies or morphological charters.

Reference models: Following the pattern identified in the definitions section (sub-section 4.2), all reference models for representing circular business models have their elements structured around the 'value concept', building on the Value Logic framework (Richardson, 2008) or the Business Model Canvas (BMC) (Osterwalder and Pigneur, 2010) (see Table 4 for the indication of which approach was adopted by each reference model). From this anchor point the different frameworks can be classified as either 
Table 4

Conceptual frameworks for circular business models.

\begin{tabular}{|c|c|c|}
\hline Type & Publication & "Name" and description \\
\hline \multirow[t]{6}{*}{ Reference models } & Mentink (2014) & $\begin{array}{l}\text { "Business Cycle Canvas (BCC)": building on the Business Model Canvas (Osterwalder and Pigneur, 2010), this } \\
\text { tool spans the organisational boundaries to support companies to design the business cycle, which is a CE } \\
\text { system of several actors in the value chain to close a material loop. The focus is on the network view and } \\
\text { collaboration. }\end{array}$ \\
\hline & $\begin{array}{l}\text { Antikainen and } \\
\text { Valkokari (2016) }\end{array}$ & $\begin{array}{l}\text { "Framework for Sustainable Circular Business Model Innovation": this is an elements-based diagram } \\
\text { inspired by the Business Model Canvas (BMC) (Osterwalder and Pigneur, 2010). It contains fourteen } \\
\text { elements, differing from the BMC as: }\end{array}$ \\
\hline & & $\begin{array}{l}\text { - Some elements were expanded: "stakeholders" instead of "customer relationships"; "reverse logistics" } \\
\text { was added to "channels"; } \\
\text { - New elements were added: "trends and drivers"; "stakeholder involvement"; "sustainability impacts"; } \\
\text { "sustainability benefits"; and "sustainability and circularity evaluation". }\end{array}$ \\
\hline & $\begin{array}{l}\text { Lewandowski } \\
\text { (2016) }\end{array}$ & $\begin{array}{l}\text { "Circular Business Model Canvas (CBMC)": this is an elements-based diagram inspired by the BMC } \\
\text { (Osterwalder and Pigneur, 2010). It contains eleven elements, differing from the BMC as: } \\
\text { - New elements were added: "take back systems"; "adoption factors"; } \\
\text { - A definition of new relationships between the elements was proposed; } \\
\text { - Predefined attributes (or options) to fill in the BM elements were suggested. For instance, options for } \\
\text { defining the element value proposition in a CBM are PSS, Circular Product, Virtual Service, Incentives } \\
\text { for customer Take-Back. }\end{array}$ \\
\hline & Bocken et al. (2018) & $\begin{array}{l}\text { "Adapted sustainable business model canvas": this is an elements-based diagram inspired by the value logic } \\
\text { (Richardson, 2008) and the BMC (Osterwalder and Pigneur, 2010). It contains eight elements, differing from } \\
\text { the BMC as: } \\
\text { - The value proposition was divided in three categories for "Profit, People and Planet"; } \\
\text { - Single or several elements were adjustment, reorganised or extended. }\end{array}$ \\
\hline & Nußholz (2018) & $\begin{array}{l}\text { "Circular business model mapping tool": this is an elements-based diagram inspired by the value logic } \\
\text { (Richardson, 2008) and the BMC (Osterwalder and Pigneur, 2010). It contains ten elements, differing from } \\
\text { the BMC as: } \\
\text { - A new element was added: 'offer'; } \\
\text { - A matrix structure to analyse the BM elements throughout different life-cycle stages was proposed; } \\
\text { - Single or several elements were adjustment, reorganised or extended. }\end{array}$ \\
\hline Requirements & $\begin{array}{l}\text { Aminoff et al. } \\
\text { (2017) }\end{array}$ & $\begin{array}{l}\text { They present a framework showing the required generic changes in value creation and delivery, value } \\
\text { capture, and value proposition for shaping CBMs. }\end{array}$ \\
\hline
\end{tabular}

Classifications (typologies, taxonomies, Bocken et al. (2016) They present a framework describing CBM strategies and types, matching them with product design morphological charters) strategies for $\mathrm{CE}$, and accompanying case studies. Six CBM types according to different strategies were described:

- Slowing loops: "access and performance models"; "extending product value"; "classic long-life model”; "encourage sufficiency".

- Closing loops: "extend resource value", "industrial symbiosis".

Moreno et al. (2016) They present a framework to link CBM archetypes and circular product design strategies.

Five CBM archetypes were systematised from previous literature and had their contribution to value flows (e.g. strategies) outlined:

- Slowing resource loops: "sharing platforms", “extending product value"

- Cycling for longer: "product life extension"

- Cascaded uses or narrowing resource flows: "resource value", "circular supplies"

Urbinati et al. They propose a taxonomy for CBMI based on the degree of adoption of circularity and changes promoted in (2017) the business models of companies. The taxonomy contains three categories:

- "Downstream circular": CBMI driven by altering value capture and delivery sub-models of the business model, through new revenue schemes and customer interface - e.g. pay-per-use models.

- "Upstream circular": CBMI driven by changing value creation sub-model of the business model - e.g. reverse logistics, product design.

- "Fully circular": combines upstream and downstream categories, i.e., all sub-systems of the business model are changed to promote the CBMI.

Geissdoerfer et al. They propose a framework describing CBM strategies, which builds on Bocken et al. (2016) and expands CBM (2018a) strategies proposed by the former by including "intensifying" and "dematerialising" in addition to "narrowing", "slowing" and "closing loops".

Planing (2018) They systematise a CBM typology with nine archetypes based on previous literature: "Access model/ collaborative consumption"; "Performance model/products as services/result-based models"; "Reuse/ refurbish/maintain/redistribute/next-life sales"; "Hybrid model/gap exploiter model”; "Remanufacturing next-life sales"; “Upgrading”; “Product transformation”; "Product recycling/Recycling 2.0"; "Energy recovery".

Diaz Lopez et al. Based on 143 case studies, they propose to explain CBMs in terms of:

(2019) - Resource efficiency measures (REM) for CBMs, divided in "supply side", "demand side" and "life cycle";

- Desirable changes in business model elements;

- Implementation barriers for CBMs;

- Degree of change in terms of BM elements and scope of change in terms of boundaries of analysis (e.g. firm-centric, value chain) for each REM.

Yang et al. (2018) They propose a taxonomy and research framework of how PSS business models (i.e. "product-oriented", "use-oriented", "result-oriented") contribute to value creation for circularity (e.g. "inner circle", "cycling for longer", "cascaded use, pure circles").

Lüdeke-Freund Employing morphological analysis to explore the configuration of elements of 26 CBM archetypes available et al. (2019) in literature, the authors proposed a morphological charter with the identification of six CBM patterns: 
Table 4 (continued)

\begin{tabular}{|c|c|c|}
\hline Type & Publication & "Name" and description \\
\hline & \multirow{3}{*}{ Whalen (2019) } & $\begin{array}{l}\text { "repair and maintenance"; "reuse and redistribution"; "refurbishment and remanufacturing"; "recycling"; } \\
\text { "cascading and repurposing"; and "organic feedstock business model". }\end{array}$ \\
\hline & & $\begin{array}{l}\text { Based on } 56 \text { case studies, the author proposes three sub-types for the CBM archetype Extending Product Value } \\
\text { (Bocken et al., 2016): "facilitators", "redistributors" or "doers". }\end{array}$ \\
\hline & & $\begin{array}{l}\text { Differently than the types applied by other frameworks (i.e. commonly describing a combination of elements } \\
\text { for designing CBMs), the proposed sub-types refer to possible roles of actors executing the activities for }\end{array}$ \\
\hline
\end{tabular}

adding new elements, adjusting existing elements to accommodate circular business model characteristics, or reorganising the positioning or relationship among elements. Recurrently added elements were related to strategic measures such as drivers for circular economy (Antikainen and Valkokari, 2016; Lewandowski, 2016); impacts on environmental, social or economic aspects (Bocken et al., 2018; Antikainen and Valkokari, 2016)); and enablers for circular economy (i.e. take-back systems (Lewandowski, 2016)).

The majority of the reference models (Nußholz, 2018; Bocken et al., 2018; Antikainen and Valkokari, 2016; Lewandowski, 2016) also follow the Business Model Canvas format with an elementsbased diagram and the consideration of an organisation-centric analysis. Exceptions are NuBholz (2018) and Mentink (2014), who proposed more comprehensive modifications of the BMC tool. Nußholz (2018) included a matrix structure to analyse the circular business model elements throughout different life-cycle stages, while Mentik (2014) expanded the boundaries of the circular business model to several organisations, creating a 'loop of interconnected business models from different organisations' to form a circular business model. While this increases the complexity of the analysis, making it more abstract and less concise, it can adds detail and provides additional descriptive capacity for circular business model representations and value flows in practice.

Requirements: Only one article describes requirements (Aminoff et al., 2017). It builds on the value concept (Richardson, 2008) and shows required changes in value creation and delivery, value capture, and value proposition for shaping circular business models. A disadvantage of this conceptual framework is the lack of precision, since it does not differentiate circular business model strategies or types to propose the changes.

Classifications: As the most recurrent conceptual frameworks, they can be divided in three perspectives: typologies, taxonomies, morphological charters. The majority of them show archetypes or types of circular business models (i.e. how to design different circular business model alternatives by configuring business model elements differently) (Moreno et al., 2016; Planing, 2018; Diaz Lopez et al., 2019; Yang et al., 2018; Bocken et al., 2016; LüdekeFreund et al., 2019). One exception (Whalen, 2019) introduces types of circular business models in regards to the role of the company (i.e. value chain) for 'extending product value'. Moreover, some of the classifications highlight how the different archetypes or types either contribute to generating benefits for circular economy in terms of strategies (e.g. slow resource flows) (Geissdoerfer et al., 2018a; Bocken et al., 2016; Moreno et al., 2016; Yang et al., 2018), or where they change the business model elements (e.g. downstream or upstream the value system) (Urbinati et al., 2017; Diaz Lopez et al., 2019; Lüdeke-Freund et al., 2019). A detailed overview of the conceptual frameworks is presented in Table 4.

In summary, the available conceptual frameworks contribute differently to adding clarity for the conceptualisation of a circular business model or a circular business model innovation. Reference models for circular business models are related to the static view of circular business model innovation (Wirtz et al., 2016), supporting the conceptualisation of how a business model should be structured or represented for circular economy. Due to this nature, these frameworks are frequently employed as tools, supporting free ideation and modelling of circular business models. Classifications are related to the dynamic view of circular business model innovation (Wirtz et al., 2016), supporting the identification of how business models should be configured or changed to accommodate circular economy principles.

Due to this nature, these conceptual frameworks are frequently employed in guided ideation sessions to accelerate the design of circular business models with benchmarking. Moreover, synergies of applying both types of conceptual frameworks are also advocated in literature. Initial attempts were performed by Aminoff et al. (2017), Lewandowski (2016) and Ludeke-Freund (2019). The first two articles provide a preliminary idea of how to do it. The last article brings a more sophisticated view of a morphologic charter showing how different circular business model types require different configurations of business model elements. Nevertheless, it does not focus on the link of how the six identified business model patterns contribute to generating strategic benefits for circular economy (i.e. strategies such as cycling, extending, intensifying, and dematerialising) and the organisation. Additionally, the last framework is based on morphological analysis and represented as a morphologic box, which is more adequate for the application in computational tools (Ritchey, 2002; Remane et al., 2017), turning the representation for conceptual and cognitive purposes complex.

\section{Discussion}

This section discusses the key findings of the study and how these findings serve the research objective of promoting the systematisation of knowledge to reduce the lack of clarity around the concepts of circular business model and circular business model innovation.

Enhanced clarity for the circular business model concept: Next to an overview of the concepts history (section 4.1) and the synthesis of a unified definition (section 4.2), four circular business model strategies were identified - i.e. cycling, extending, intensifying and dematerialising (Fig. 3 in section 4.2). Combining these strategies Richardson's (2008) value logic (i.e. value proposition, value creation and delivery, and value capture) inherent in most of the reviewed definitions, we can discuss how the implementation of these four circular business model strategies will affect the three business model elements according to recommendations compiled from the reviewed publications (Fig. 5).

Cycling entails the implementation of a number of end-of-use strategies, such as reuse, repair and remanufacturing. From a value proposition perspective, take-back is a key element of the value proposition, which is enabled by collaborations in the value chain and effective reverse manufacturing processes (such as repair, remanufacture, refurbish and recycling). In this case, value capture is mainly related to minimised costs of material acquisition and additional revenues from end-of-use products/materials. As this strategy increases the longevity of cores or materials, it presents the environmental potential to reduce both energy and new materials intake and waste output. 


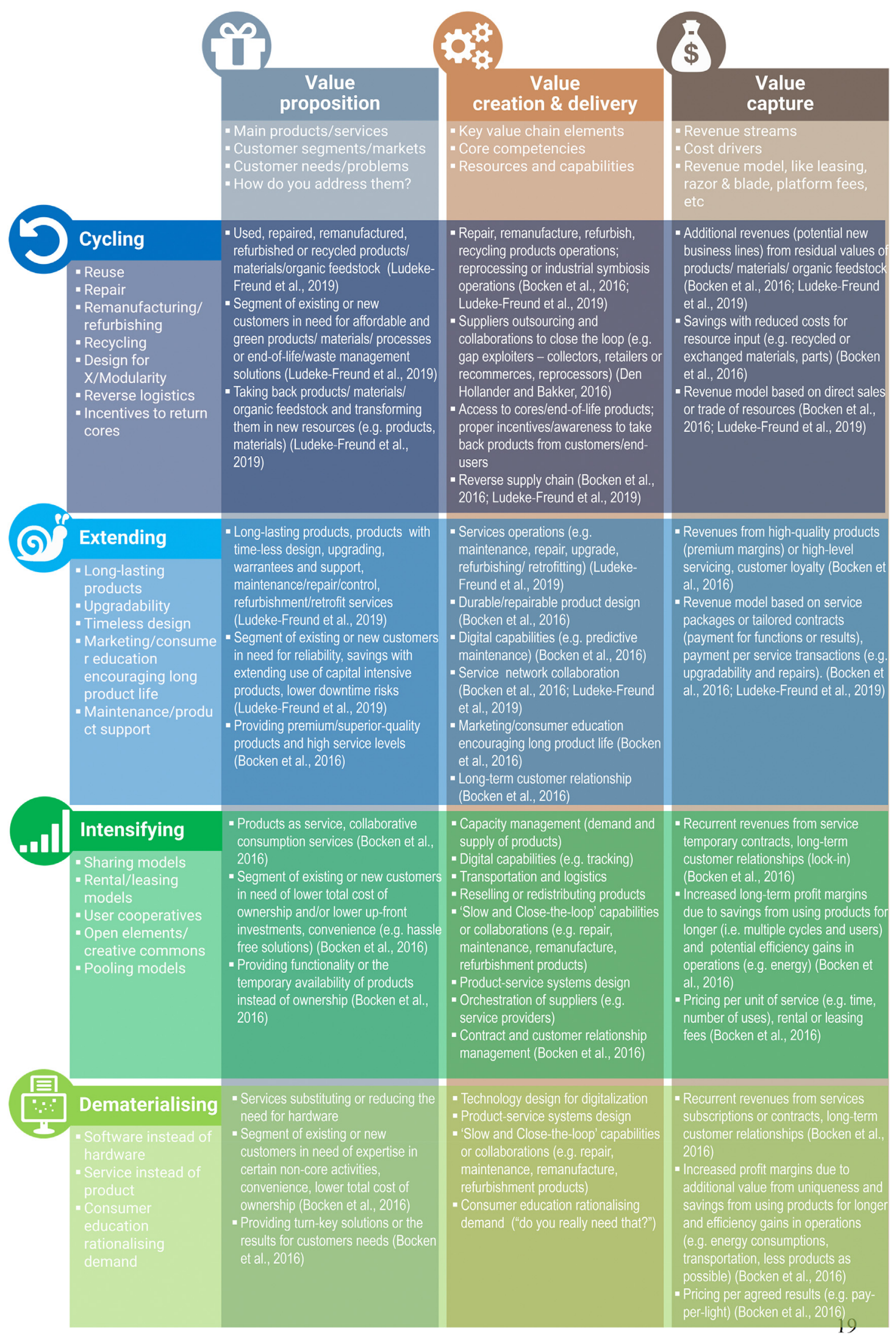

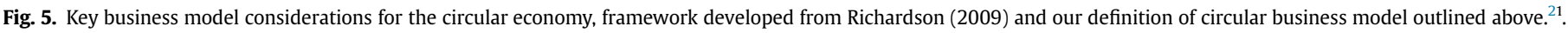


Extending aims at keeping the product in use to the highest extent possible, being mainly enabled by design and operation practices. Long-life products (value proposition) that are serviced during its lifetime can create a long-term customer relationship (value creation \& delivery), and create new revenue streams during the use phase of the products through service packages or tailored contracts. The implementation of this strategy lead to reduced need for producing new products.

Intensifying leads to the implementation of new value propositions around sharing models, being enabled by capacity management, digital capabilities and customer relationship management. Intensifying enables new business models with stronger servitisation elements, such as PSS, which results in recurrent revenue streams. The main environmental benefits of this strategy are reduced idle time or structural waste (disposal of product before specification lifetime), leading to reduced need for producing new products and reduced waste output.

Dematerialising decreases the use of physical resources by enhancing the value created by intangible solutions, such as services and software. Value creation \& delivery is ensured though slow and close the loop capabilities and collaborations. Recurrent revenues, increased profit margins and new pricing mechanisms are key elements for value capture.

It is important that these four strategies can also be combined within one business model, especially within a business model ecosystem, as outlined below.

Enhanced clarity for the circular business model innovation concept: Next to the synthesis of a unified definition (presented in section 4.2) and the identification of different circular business model innovation strategies - circular start-ups, CBM transformation, CB diversification and CBM acquisitions (Fig. 4, section 4.2), our analysis of publications indicates that different circular business model innovation strategies might promote different circular economy outcomes (i.e. resource input and waste/emission output).

Of these strategies, the 'transformation' might have the highest potential impact, especially, if it replaces an existing linear model with a circular one. The 'start-up' and 'diversification' strategies are very similar in nature. Whether the new business model is build inhouse by an existing corporation or outside of its boundaries by a new entity, both might introduce similar new circular solutions. Disruptive innovation theory suggests that start-ups might yield more radical solutions with more - in this case circular economy impact (Christensen, 1997). However, nascent research on business building units indicates that this might hold true within an industry rather than across sectors (Geissdoerfer, 2019). In many cases, however, the two strategies might also shift or even reinforce environmental impact by creating new markets, additional resource sinks, or previously non-existing demand (Kjaer et al., 2019). With the 'acquisition' strategy, the resource efficiency gains might be either enhanced or reduced depending on the success of integration and the associated realisation of synergies among business models - here we would e.g. expect improved results from industrial organisation and reduced ones from agency theory, also depending on relatedness of the businesses involved (Palich et al., 2000; Eisenhardt, 1989; Tirole and Jean, 1988).

Strategic alliances (Mowery et al., 1996; Gulati, 1998; Hamel, 1991 ) could also be of interest, because of the important role of ecosystem partnerships, but this is not yet discussed in the literature. Alliances can be an enabler for the different strategies, for example in the context of circular business model transformation,

\footnotetext{
${ }^{2}$ We have also successfully used this framework as an ideation workshop tool in educational and industrial settings - think of sticky notes instead of bullet points in the 12 "darker" fields from the lower right - see poster in the appendix.
}

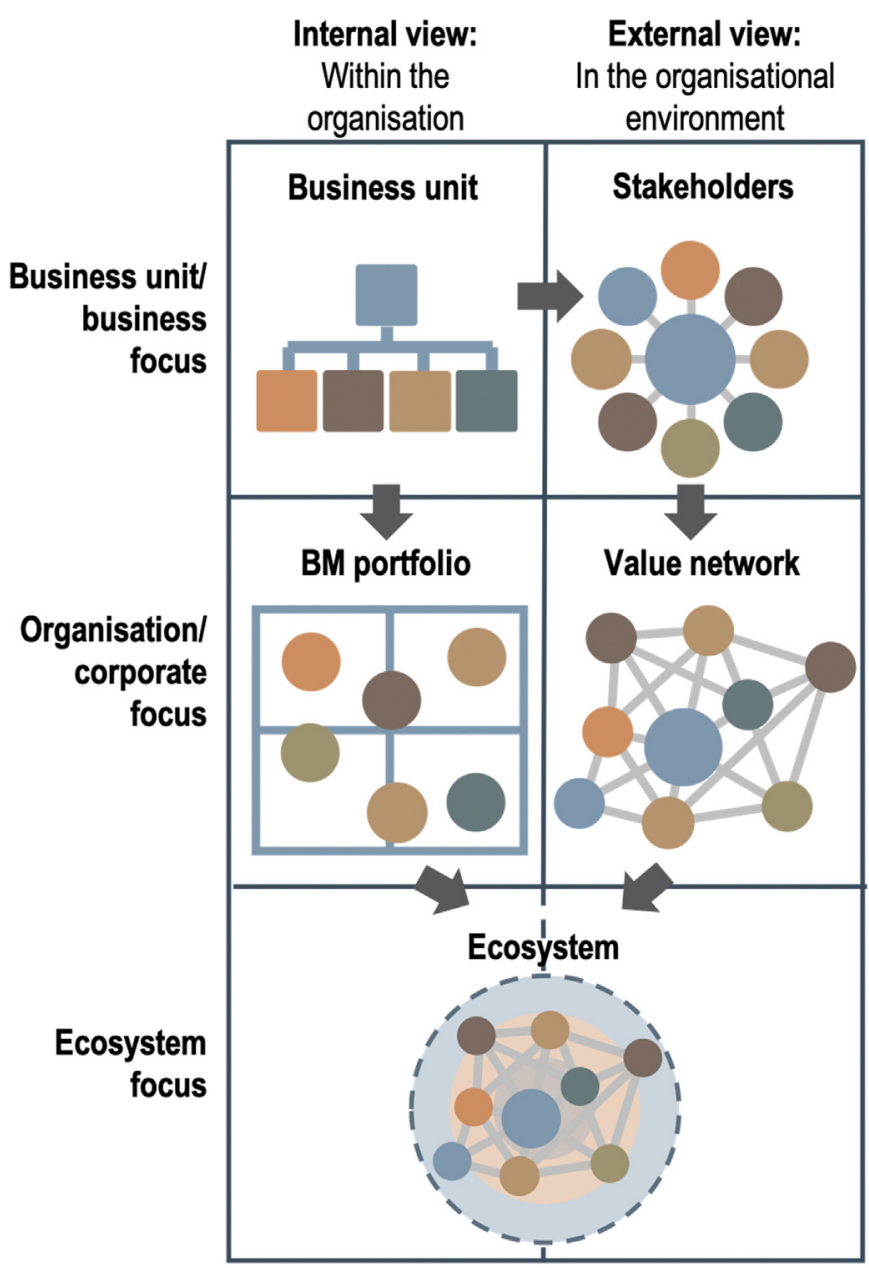

Fig. 6. Unit of analysis for business model innovation.

beverage companies in Denmark have teamed up with municipalities to create a coordination entity to manage the return systems for packaging recycling (State of Green, 2016). And, in the context of circular start-ups, Norsk Ombruk has developed alliances with Waste Electrical and Electronic Equipment (WEEE) take back systems in Norway and white goods manufacturers, like Electrolux (Nordic Council of Ministers, 2015; Townsend, 2017).

The reviewed literature also points to a shift in the unit of analysis that is already partly covered in the conventional and sustainable business model innovation literature. We would expect this shift to be emphasised in the context of the circular economy with its particular need for stakeholder collaboration and systemic ecosystem view (Pieroni et al., 2019a). We have illustrated the shift in the unit of analysis in Fig. 6.

Most conceptualisations of the business model notion seem to be implicitly or explicitly based on the value chain concept (see e.g. Richardson, 2008; Magretta, 2002; Osterwalder and Pigneur, 2010). Since the unit of analysis of the value chain is the business unit (Porter, 2004), this is can also be assumed to be the unit of analysis for the overarching business model concept. While some authors refer to the company or firm to be at the centre of their business model notion, this line of argument is more convincing for single-product ${ }^{3}$ companies or firms with a homogeneous portfolio (see e.g. Osterwalder and Pigneur, 2010; Zott et al., 2010; Chesbrough, 2010).

\footnotetext{
${ }^{3}$ Product in the sense of product or service.
} 
The focus of this conceptualisation can be expanded in two directions: (i) from the intra-organisational perspective to the organisational environment and (ii) from the business unit to the corporate view.

Concerning the environment, the focus can be expanded by the addition of different stakeholders to the analysis. This is based on stakeholder management theory (Donaldson and Preston, 1995; Freeman, 1984; Post et al., 2002) and seems to be particularly influencing business model notions aimed at sustainability (see e.g. Bocken et al., 2013; Geissdoerfer et al., 2017; Pieroni et al., 2019).

There are also nascent approaches to expand the business model concept to the corporate or multi-business unit view, via portfolio management of several business units within one corporation (Henderson, 1973; Cooper et al., 1998), for example by Höök et al. (2015) and Aversa et al. (2017). This also bridges the gap from the use of the business model concept in business strategy to the corporate strategy context.

If the stakeholder view is further expanded towards a multibusiness view, this results in the value network (Velu and Stiles, 2013; Zott and Amit, 2010). While still being organisation-centric, this view generally puts greater emphasis on value exchanges between stakeholders - not only between the stakeholder and the focal organisation, but also between other stakeholders.

The value network and business model portfolio perspective can be combined to an ecosystem view (Iansiti and Levien, 2004; Clarysse et al., 2014). Besides combining multi-business model and multistakeholder views into a network perspective, ecosystem analyses can also expand not only to several business units but entire organisations (i.e. a multi-corporation view). The concept can thus can go beyond current corporate strategy considerations that it combines with industry analysis elements, while emphasising collaborative and regularly underinvestigating competitive elements of both.

From our analyses of the publications that emerged in the literature review, the difference between the stakeholder and the value network view seem to be ambiguous in the circular business model literature. The stakeholder-based literature seems to group stakeholders more often and, as an expansion of the value chain, the value network tends to have some more emphasis on analysing the transactions between the nodes (see e.g. Bocken et al., 2013; Geissdoerfer et al., 2017; Velu and Stiles, 2013). The portfolio and the ecosystem views might be particularly interesting for circular business models, given the circular economy's considerable emphasis on the interaction of diverse players within the ecosystem (Webster, 2015; Pieroni et al., 2019a). However, in most of the reviewed literature, the portfolio element was underrepresented and the ecosystem concept employed by some authors was identical with the value network notion (Christensen and Rosenbloom, 1995; Moore, 1993; Vasconcelos et al., 2018).

\section{Conclusions}

We conducted this review to increase the conceptual clarity around the notions of circular business model and circular business model innovation.

The key contributions of this paper are: (1) an overview of the history of the concept; (2) an overview and synthesis of definitions of the circular business model and circular business model innovation concept; and (3) an overview and synthesis of conceptual frameworks. Moreover, by contributing to reducing the conceptual lack of clarity and mapping the research landscape, we provide a sturdier basis for the emerging field of the circular business model innovation. This paves the way for a common understanding and language that can be used to develop the theoretical concept and a conceptual anchor for the nascent empirical exploration of the field. The increased clarity and simplicity in communicating what circular business models are and how they are innovated can ultimately lead to the development of research that will support academics and industry practitioners with decision-making and adoption of CBMs.

The limitations of this work derive mostly from the employed methodologies for our literature review. Our search-string based on database search does not include contributions that are not published in academic journals in the initial sample. This is to a certain extent mitigated by the conducted cross-reference snowballing. However, the snowballing can suffer from a lack of randomised representativeness, mirroring the selection bias represented in the reviewed literature.

Opportunities for future research: The discussed limitations can be overcome by further research, using different methodological techniques to both test the validity of our results and clarify the contexts in which they might not be applicable. We would particularly recommend testing the synthesised frameworks for circular business model innovation strategies and key business model considerations - Figs. 3 and 4 - with organisational case studies. A particular focus should lie on the impact of the four CBM and four CBMI strategies on circular economy and sustainability impact and how disruptive they are to current linear models. We also encourage to combine the different frameworks provided in the figures to form investigative models and hypotheses - think matrices. Examples include which of the four CBM strategies works best with which of the CBMI strategies (Figs. 3 and 4) or which strategy is best covered by which unit of analysis (Figs. 3 and 6). Of course, the framework in Fig. 5 would also lend itself to further investigation. We have also observed a shift in the unit of analysis in circular economy business model innovation from the business unit to the ecosystem. The conceptual consequences of this shift provide a whole range of new research avenues and the potential of this shift for implementing a circular economy should be empirically investigated. For the nascent concept of business model ecosystems, we would recommend to work towards a stronger integration of value network and business model portfolio considerations to achieve a more holistic tool for corporate and circular economy settings.

\section{Declaration of competing interest}

The authors declare that they have no known competing financial interests or personal relationships that could have appeared to influence the work reported in this paper.

\section{Acknowledgements}

This work was supported by the EPSRC Centre for Innovative Manufacturing in Industrial Sustainability, grant number EP/I033351/ 1 and the EPSRC project Business Models for Sustainable Industrial Systems, grant number EP/L019914/1, as well as studentships from the EPSRC and the Foundation of German Business. This work was also supported by the research project CIRCit (Circular Economy Integration in the Nordic Industry for Enhanced Sustainability and Competitiveness), which is part of the Nordic Green Growth Research and Innovation Programme (grant number 83144) and jointly funded by NordForsk, Nordic Energy Research, and Nordic Innovation. The authors would like to thank the funding agencies for the support.

\section{Appendix A. Supplementary data}

Supplementary data to this article can be found online at https://doi.org/10.1016/j.jclepro.2020.123741.

Appendix. Workshop poster version of Fig. 5 


\section{Circular Business Model Tool}

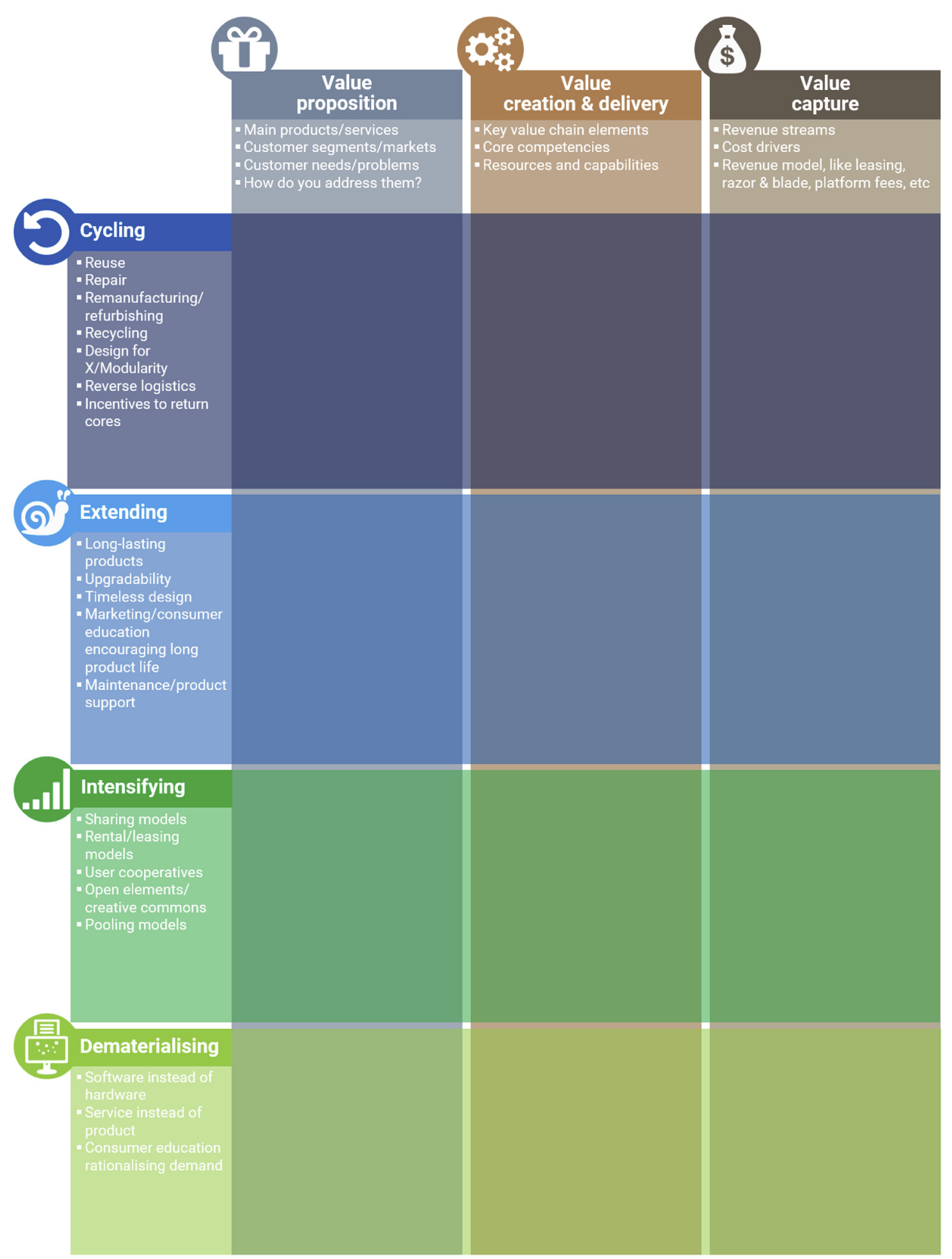

Source: Geissdoerfer, M.; Pieroni, M.; Pigosso, D.; Soufani, K. (under review). Circular business models: A review. Journal of Cleaner Production. 


\section{References}

Afuah, A., 2004. Business Models: A Strategic Management Approach. McGraw-Hill/ Irwin, Boston.

Aminoff, A., Valkokari, K., Antikainen, M., Kettunen, O., 2017. Exploring disruptive business model innovation for the circular economy. In: Cimatti, B., Campana, G., Howlett, R., Setchi, R. (Eds.), Sustainable Design and Manufacturing 2017. SDM 2017. Springer, Cham, pp. 525-536.

Andal-Ancion, A., Cartwright, P.A., Yip, G.S., 2004. The digital transformation of traditional business. MIT Sloan Manag. Rev. 45 (2), 26-32.

Andersen, M.S., 2007. An introductory note on the environmental economics of the circular economy. Sustain. Sci. 2 (1), 133-140. http://link.springer.com/10.1007/ s11625-006-0013-6.

Annarelli, A., Battistella, C., Nonino, F., 2016. Product service system: a conceptual framework from a systematic review. J. Clean. Prod. 139, 1011-1032. https:/ doi.org/10.1016/j.jclepro.2016.08.061.

Antikainen, M., Valkokari, K., 2016. A framework for sustainable circular business model innovation. Technol. Innovat. Manag. Rev. 6 (7), 5-12.

Aversa, P., Haefliger, S., Reza, D.G., 2017. Building a winning business model portfolio. MIT Sloan Manag. Rev. 58 (4), 49-54.

Baines, T.S., Lightfoot, H.W., Benedettini, O., Kay, J.M., 2009. The servitization of manufacturing: a review of literature and reflection on future challenges. J. Manuf. Technol. Manag. 20 (5), 547-567.

Benyus, J.M., 2002. Biomimicry. Harper Perennial, New York.

Berman, S.J., 2012. Digital transformation: opportunities to create new business models. Strat. Leader. 40 (2), 16-24.

Bi, Z.M., Liu, Y., Baumgartner, B., Culver, E., Sorokin, J.N., Peters, A., Cox, B. Hunnicutt, J., Yurek, J., O'Shaughnessey, S., 2015. Reusing industrial robots to achieve sustainability in small and medium-sized enterprises (SMEs). Ind. Robot: Int. J. 42 (3), 264-273.

Bieger, T., Reinhold, S., 2011. Das wertbasierte geschäftsmodell-ein aktualisierter strukturierungsansatz. In: Bieger, Thomas, zu Knyphausen-Aufseß, Dodo, Krys, Christian (Eds.), Innovative Geschäftsmodelle. Springer, Berlin, Heidelberg.

Birkin, F., Polesie, T., Lewis, L., 2009. A new business model for sustainable development: an exploratory study using the theory of constraints in Nordic organizations. Bus. Strat. Environ. 18 (5), 277-290. https://doi.org/10.1002/bse.581.

Blomsma, F., Brennan, G., 2017. The emergence of circular economy: a new framing around prolonging resource productivity. J. Ind. Ecol. 21 (3), 603-614. https:/ doi.org/10.1111/jiec.12603.

Bocken, N., Short, S., Rana, P., Evans, S., 2013. A value mapping tool for sustainable business modelling. Corporate Governance 13 (5), 482-497. https://doi.org 10.1108/CG-06-2013-0078.

Bocken, N.M.P., Short, S.W., Rana, P., Evans, S., 2014. A literature and practice review to develop sustainable business model archetypes. J. Clean. Prod. 65, 42-56.

Bocken, N.M.P., de Pauw, I., Bakker, C., van der Grinten, B., 2016. Product design and business model strategies for a circular economy. J. Ind. Prod. Eng. 33 (5), 308-320. https://doi.org/10.1080/21681015.2016.1172124.

Bocken, N.M., Ritala, P., Huotari, P., 2017. The circular economy: exploring the introduction of the concept among S\&P 500 firms. J. Ind. Ecol. 21 (3), 487-490.

Bocken, N.M.P., Schuit, C.S.C., Kraaijenhagen, C., 2018. Experimenting with a circular business model: lessons from eight cases. Environ. Innovat. Soc. Transit. 28, 79-95. https://doi.org/10.1016/j.eist.2018.02.001. February.

Bocken, N., Strupeit, L., Whalen, K., Nußholz, J., 2019. A review and evaluation of circular business model innovation tools. Sustainability 11 (8), 2210. https:// www.mdpi.com/2071-1050/11/8/2210.

Boons, F., Lüdeke-Freund, F., 2013. Business models for sustainable innovation: state-of-the-art and steps towards a research agenda. J. Clean. Prod. 45, 9-19. https://doi.org/10.1016/j.jclepro.2012.07.007.

Boulding, K.E., 1966. The economics of the coming spaceship earth. Environ. Qual. Grow. Eco.: Essays from the Sixth RFF Forum 3-14.

Brennan, G., Tennant, M., Blomsma, F., 2015. Business and production solutions: closing loops and the circular economy. In: Helen, Kopnina, Eleanor, ShoremanOuimet (Eds.), Sustainability: Key Issues. Routledge: EarthScan, ISBN 9780415529860, pp. 219-239. Key Issues in Environment and Sustainability.

Bressanelli, G., Adrodegari, F., Perona, M., Saccani, N., 2018. ScienceDirect the Role of Digital Technologies to Overcome Circular Economy Challenges in PSS Busines Models : an Exploratory Case Study 00, pp. 29-31. May,

Casadesus-Masanell, R., Ricart, J.E., 2010. From strategy to business models and onto tactics. Long. Range Plan. 43 (2-3), 195-215.

Casadesus-Masanell, R., Zhu, F., 2013. Business model innovation and competitive imitation: the case of sponsor-based business models. Strat. Manag. J. 34 (4), $464-482$.

Chesbrough, H., 2007. Business model innovation: it's not just about technology anymore. Strat. Leader. 35 (6), 12-17.

Christensen, C.M., 1997. The Innovator's Dilemma: when New Technologies Cause Great Firms to Fail. Harvard Business Press.

Christensen, C.M., Overdorf, M., 2000. Meeting the challenge of disruptive change. Harv. Bus. Rev, 78 (2), 66-76.

Christensen, C.M., Rosenbloom, R.S., 1995. Explaining the attacker's advantage: technological paradigms, organizational dynamics, and the value network. Res. Pol. 24 (2), 233-257.

Clarysse, B., Wright, M., Bruneel, J., Mahajan, A., 2014. Creating value in ecosystems: crossing the chasm between knowledge and business ecosystems. Res. Pol. 43 (7), 1164-1176.
Commoner, B., 1971. The Closing Circle: Nature, Man, and Technology, first ed. Knopf, New York.

Cooper, R.G., Edgett, S.J., Kleinschmidt, E.J., 1998. Best practices for managing R\&D portfolios. Res. Technol. Manag. 41 (4), 20-33.

de Almeida Biolchini, J.C., Mian, P.G., Natali, A.C.C., Conte, T.U., Travassos, G.H., 2007. Scientific research ontology to support systematic review in software engineering. Adv. Eng. Inf. 21 (2), 133-151. http://linkinghub.elsevier.com/retrieve/ pii/S147403460600070X.

Den Hollander, M., Bakker, C., 2016. Mind the gap exploiter: circular business models for product lifetime extension. In: Proceedings of Electronic Goes Green 2016+, vols. 1-8. Fraunhofer IZM Berlin, Berlin.

Diaz Lopez, F.J., Bastein, T., Tukker, A., 2019. Business model innovation for resourceefficiency, circularity and cleaner production: what 143 cases tell us. Ecol. Econ. 155, 20-35. March 2017. https://www.sciencedirect.com/science/article/pii/ S0921800917303294.

Doleski, O.D., 2015. Integrated Business Model: Applying the St. Gallen Management Concept to Business Models. Springer, Berlin.

Donaldson, T., Preston, L.E., 1995. The stakeholder theory of the corporation: concepts, evidence, and implications. Acad. Manag. Rev. 20 (1), 65-91.

Dresch, A., Lacerda, D.P., Antunes Jr., J.A.V., 2015. Design Science Research. Springer International Publishing, Cham, Switzerland. http://www.springer.com/gb/ book/9783319073736.

Eisenhardt, K.M., 1989. Agency theory: an assessment and review. Acad. Manag. Rev. 14 (1), 57-74.

EMF, 2012. Towards the Circular Economy Vol. 1: Economic and Business Rationale for an Accelerated Transition. Ellen MacArthur Foundation Publishing. https:// www.ellenmacarthurfoundation.org/assets/downloads/publications/EllenMacArthur-Foundation-Towards-the-Circular-Economy-vol.1.pdf. (Accessed 1 December 2017).

EMF, 2014. Towards the Circular Economy Vol. 3: Accelerating the Scale-Up across Global Supply Chains.

EMF, 2015. Towards a Circular Economy: Business Rationale for an Accelerated Transition. https://www.ellenmacarthurfoundation.org/assets/downloads/TCE Ellen-MacArthur-Foundation_9-Dec-2015.pdf. (Accessed 30 June 2018).

Esposito, M., Tse, T., Soufani, K., 2016. Companies Are Working with Consumers to Reduce Waste: Business Source. Harvard Business Review Online Articles.

European Commission, 2015. Closing the Loop: Commission Adopts Ambitious New Circular Economy Package to Boost Competitiveness, Create Jobs and Generate Sustainable Growth. European Comission Press Release.

Evans, S., Gregory, M., Ryan, C., Bergendahl, M., Tan, A., 2009. Towards a Sustainable Industrial System: with Recommendations for Education, Research, Industry and Policy. University of Cambridge, Cambridge.

Foss, N.J., Saebi, T., 2017. Fifteen years of research on business model innovation. J. Manag. 43 (1), 200-227. http://journals.sagepub.com/doi/10.1177/ 0149206316675927.

Freeman, R., 1984. Strategic Management: A Stakeholder Approach. Pitman, Boston.

Geissdoerfer, M., 2019. Sustainable Business Model Innovation: Process, Challenges and Implementation. University of Cambridge.

Geissdoerfer, M., Bocken, N.M.P., Hultink, E.J., 2016. Design thinking to enhance the sustainable business modelling process - a workshop based on a value mapping process. J. Clean. Prod. 135, 1218-1232. https://doi.org/10.1016/ j.jclepro.2016.07.020

Geissdoerfer, M., Savaget, P., Bocken, N.M.P., Hultink, E.J., 2017. The Circular Economy - a new sustainability paradigm? J. Clean. Prod. 143, 757-768. January. http://10.0.3.248/j.jclepro.2016.12.048\%250Ahttps://login.e.bibl.liu.se/login? url=https://search.ebscohost.com/login.aspx?direct=true\&amp; AuthType=ip,uid\&amp; db=edselp\&amp;AN=S0959652616321023\&amp lang $=$ sv\&amp;site $=$ eds-live \&amp;scope $=$ site.

Geissdoerfer, M., Morioka, S.N., de Carvalho, M.M., Evans, S., 2018a. Business models and supply chains for the circular economy. J. Clean. Prod. 190, 712-721. http:// linkinghub.elsevier.com/retrieve/pii/S0959652618311867.

Geissdoerfer, M., Vladimirova, D., Evans, S., 2018b. Sustainable business model innovation: a review. J. Clean. Prod. 198, 401-416. https://doi.org/10.1016/ j.jclepro.2018.06.240 submitted for publication.

George, G., Bock, A.J., 2011. The business model in practice and its implications for entrepreneurship research. Enterpren. Theor. Pract. 35 (1), 83-111.

Ghisellini, P., Cialani, C., Ulgiati, S., 2016. A review on circular economy: the expected transition to a balanced interplay of environmental and economic systems. J. Clean. Prod. 114, 11-32. September. http://linkinghub.elsevier.com/ retrieve/pii/S0959652615012287.

Graedel, T.E., Allenby, B.R., 1995. Industrial Ecology. Prentice Hall, Englewood Cliffs, N.J.

Gulati, R., 1998. Alliances and networks. Strat. Manag. J. 19 (4), 293-317.

Haase, R.P., Pigosso, D.C.A., McAloone, T.C., 2017. Product/service-system origins and trajectories: a systematic literature review of PSS definitions and their characteristics. Procedia CIRP 64, 157-162. https://linkinghub.elsevier.com/retrieve/ pii/S2212827117301993.

Hamari, J., Sjöklint, M., Ukkonen, A., 2016. The sharing economy: why people participate in collaborative consumption. J. Assoc. Inf. Sci. Technol. 67 (9), 2047-2059.

Hamel, G., 1991. Competition for competence and interpartner learning within international strategic alliances. Strat. Manag. J. 12 (S1), 83-103.

Hamel, G., 2000. Leading the Revolution. Harvard Business School Press, Boston.

Hauschild, M., Jeswiet, J., Alting, L., 2005. From life cycle assessment to sustainable production: status and perspectives. CIRP Ann. - Manuf. Technol. 54 (2), 535-554. \%3CGo. 
Henderson, B., 1973. The Experience Curve Reviewed (Part IV). The Growth Share Matrix or the Product Portfolio. The Boston Consulting Group, Boston.

Homrich, A.S., Galvão, G., Abadia, L.G., Carvalho, M.M., 2018. The circular economy umbrella: trends and gaps on integrating pathways. J. Clean. Prod. 175, $525-543$.

Höök, M., Stehn, L., Brege, S., 2015. The development of a portfolio of business models: a longitudinal case study of a building material company. Construct. Manag. Econ. 33 (5-6), 334-348.

Iansiti, M., Levien, R., 2004. The Keystone Advantage: what the New Dynamics of Business Ecosystems Mean for Strategy, Innovation, and Sustainability. Harvard Business Press.

Jensen, B., 1997. Make it simple! How simplicity could become your ultimate strategy Strat. Leader. 25 (2), 35-39.

Johnson, M., 2010. Seizing the White Space: Business Model Innovation for Growth and Renewal. Harvard Business Press, Boston.

Kirchherr, J., Reike, D., Hekkert, M., 2017. Conceptualizing the circular economy: an analysis of 114 definitions. Resour. Conserv. Recycl. 127, 221-232. September. https://linkinghub.elsevier.com/retrieve/pii/S0921344917302835.

Kjaer, L.L., Pigosso, D.C.A., Niero, M., Bech, N.M., McAloone, T.C., 2019. Product service-systems for a circular economy: the route to decoupling economic growth from resource consumption? J. Ind. Ecol. 23 (1), 22-35.

Knyphausen-Aufseß, D., Meinhardt, Y., 2002. Revisiting Strategy: ein Ansatz zur Systematisierung von Geschäftsmodellen. In: Bieger, Thomas, Bickhoff, Nils, Caspers, Rolf, Knyphausen-Aufseß, Dodo, Reding, Kurt (Eds.), Zukünftige Geschäftsmodelle. Springer, Berlin, pp. 63-89.

Lahti, T., Wincent, J., Parida, V., 2018. A definition and theoretical review of the circular economy, value creation, and sustainable business models: where are we now and where should research move in the future? Sustainability 10 (8), 2799.

Laumann, L., Pagoropoulos, A., Schmidt, J.H., Mcaloone, T.C., 2016. Challenges when evaluating product/service-systems through life cycle assessment. J. Clean. Prod. 120, 95-104. https://doi.org/10.1016/j.jclepro.2016.01.048.

Lewandowski, M., 2016. Designing the business models for circular economy-towards the conceptual framework. Sustainability 8 (1), 43. http://www.mdpi. com/2071-1050/8/1/43.

Lieder, M., Rashid, A., 2016. Towards circular economy implementation: a comprehensive review in context of manufacturing industry. J. Clean. Prod. 115, 36-51. http://linkinghub.elsevier.com/retrieve/pii/S0959652615018661.

Linder, M., Williander, M., 2017. Circular business model innovation: inherent uncertainties. Bus. Strat. Environ. 26 (2), 182-196. https://doi.org/10.1002/ bse.1906.

Lindgardt, Z., Reeves, M., 2015. Business Model Innovation: when the game gets tough, change the game. In: Deimler, M., Lesser, R., Rhodes, D., Sinha, J. (Eds.), Own the Future: 50 Ways to Win from the Boston Consulting Group. John Wiley \& Sons, Hoboken, NJ.

Lüdeke-Freund, F., Dembek, K., 2017. Sustainable business model research and practice: emerging field or passing fancy? J. Clean. Prod. 168, 1668-1678. https://doi.org/10.1016/j.jclepro.2017.08.093.

Lüdeke-Freund, F., Stefan, G., Bocken, N.M.P., 2019. A review and typology of circular economy business model patterns. J. Ind. Ecol. 23 (1), 36-61. https://doi.org/ 10.1111 jiec. 12763.

Lyle, J.T., 1994. Regenerative Design for Sustainable Development. Wiley H1, New York; Chichester. British Library H2 - DSC q94/05444 H1 - British Library H2 HMNTS YC.1994.b.2516.

Magretta, J., 2002. Why Business Models Matter. Harvard Business Review. https:// hbr.org/2002/05/why-business-models-matter. (Accessed 30 June 2018).

Mankins, M., Harris, K., Harding, D., 2017. Strategy in the age of superabundant capital. Harv. Bus. Rev. 95 (2), 66-75.

Manninen, K., Koskela, S., Antikainen, R., Bocken, N., Dahlbo, H., Aminoff, A., 2018 Do circular economy business models capture intended environmental value propositions? J. Clean. Prod. 171, 413-422. https://doi.org/10.1016/ j.jclepro.2017.10.003.

Massa, L., Tucci, C., Afuah, A., 2017. A critical assessment of business model research. Acad. Manag. Ann. 11 (1), 73-104.

McDonough, W., Braungart, M., 2002. Cradle to Cradle: Remaking the Way We Make Things. North Point Press, New York.

Mentink, B. a S., 2014. Circular Business Model Innovation A Process Framework and a Tool for Business Model Innovation in a Circular Economy. Master Theis. Delft University of Technology and Leiden University.

Merli, R., Preziosi, M., Acampora, A., 2018. How do scholars approach the circular economy? A systematic literature review. J. Clean. Prod. 178, 703-722. https:// doi.org/10.1016/j.jclepro.2017.12.112.

Mitchell, D.W., Coles, C.B., 2004. Business model innovation breakthrough moves. J. Bus. Strat. 25 (1), 16-26.

Mont, O.K., 2002. Clarifying the concept of product - service system. J. Clean. Prod. $10,237-245$.

Moore, J.F., 1993. Predators and prey: the new ecology of competition. Harward Business Review 71 (3), 75-83.

Moreno, M., De los Rios, C., Rowe, Z., Charnley, F., 2016. A conceptual framework for circular design. Sustainability 8 (9), 937. http://www.mdpi.com/2071-1050/8/9/ 937.

Mowery, D.C., Oxley, J.E., Silverman, B.S., 1996. Strategic alliances and interfirm knowledge transfer. Strat. Manag. J. 17 (S2), 77-91.

Murray, A., Skene, K., Haynes, K., 2017. The circular economy: an interdisciplinary exploration of the concept and application in a global context. J. Bus. Ethics 140
(3), 369-380. http://link.springer.com/10.1007/s10551-015-2693-2.

Naas, R., 2015. Patek philippe celebrates 20 Years of its iconic advertising campaign. Forbes Online Dec (9).

Nidumolu, R., Prahalad, C.K., Rangaswami, M.R., 2009. Why sustainability is now the key driver of innovation. Harv. Bus. Rev. 87 (9), 56-64.

Niero, M., Hauschild, M.Z., Hoffmeyer, S.B., Olsen, S.I., 2017. Combining ecoefficiency and eco-effectiveness for continuous loop beverage packaging systems: lessons from the carlsberg circular community. J. Ind. Ecol. 21 (3), 742-753. https://doi.org/10.1111/jiec.12554.

Nordic Council of Ministers, 2015. Moving towards a circular economy. http:// norden.diva-portal.org/smash/get/diva2:852029/FULLTEXT01.pdf. (Accessed 1 July 2017).

Nußholz, J., 2017. Circular business models: defining a concept and framing an emerging research field. Sustainability 9 (10), 1810. http://www.mdpi.com/ 2071-1050/9/10/1810.

Nußholz, J.L.K., 2018. A circular business model mapping tool for creating value from prolonged product lifetime and closed material loops. J. Clean. Prod. 197, 185-194. https://www.sciencedirect.com/science/article/pii/S0959652618317621.

Oghazi, P., Mostaghel, R., 2018. Circular business model challenges and lessons learned —an industrial perspective. Sustainability 10 (3), 739.

Osterwalder, A., Pigneur, Y., 2010. Business Model Generation. John Wiley \& Sons Hoboken.

Osterwalder, A., Pigneur, Y., Tucci, C.L., 2005. Clarifying business models. Commun. Assoc. Inf. Syst. 16 (1), 1-40.

Palich, L.E., Cardinal, L.B., Miller, C.C., 2000. Curvilinearity in the diversification-performance linkage: an examination of over three decades of research. Strat. Manag. J. 21 (2), 155-174.

Parida, V., Sjödin, D., Reim, W., 2019. Reviewing literature on digitalization, business model innovation, and sustainable industry: past achievements and future promises. Sustainability 11 (2).

Parker, G., Van Alstyne, M., Choudary, S.P., 2017. Platform Revolution : How Networked Markets Are Transforming the Economy and How to Make Them Work for You. W. W. Norton \& Company, New York.

Pauli, G.A., 2010. The Blue Economy: 10 Years, 100 Innovations, 100 Million Jobs. Paradigm Publications, Taos, NM.

Pearce, D., Turner, R., 1989. Economics of Natural Resources and the Environment Johns Hopkins University Press, Baltimore.

Pieroni, M., McAloone, T., Pigosso, D., 2019a. Configuring new business models for circular economy through product-service systems. Sustainability 11 (13), 3727. https://www.mdpi.com/2071-1050/11/13/3727.

Pieroni, M.P.P., McAloone, T.C., Pigosso, D.C.A., 2019b. Business model innovation for circular economy and sustainability: a review of approaches. J. Clean. Prod. 215, 198-216. https://linkinghub.elsevier.com/retrieve/pii/S0959652619300423.

Planing, P., 2018. Towards a circular economy - how business model innovation wil help to make the shift. Int. J. Bus. Glob. 20 (1), 71. http://www.inderscience. com/link.php?id=88665.

Porter, M.E., Kramer, M.R., 2011. Creating shared value: how to reinvent capitalism and unleash a wave of innovation and growth. Harv. Bus. Rev. 89 (1/2), 62-77.

Post, J.E., Preston, L.E., Sauter-Sachs, S., 2002. Redefining the Corporation: Stakeholder Management and Organizational Wealth. Stanford University Press.

Prettenthaler, F.E., Steininger, K.W., 1999. From ownership to service use lifestyle: the potential of car sharing. Ecol. Econ. 28 (3), 443-453.

Rabetino, R., Harmsen, W., Kohtamäki, M., Sihvonen, J., 2018. Structuring servitization-related research. Int. J. Oper. Prod. Manag. 38 (2), 350-371. http:/ www.emeraldinsight.com/doi/10.1108/IJOPM-03-2017-0175.

Rashid, A., Asif, F.M.A., Krajnik, P., Nicolescu, C.M., 2013. Resource conservative manufacturing: an essential change in business and technology paradigm for sustainable manufacturing. J. Clean. Prod. 57, 166-177. https://doi.org/10.1016/ j.jclepro.2013.06.012

Reim, W., Parida, V., Örtqvist, D., 2015. Product-Service Systems (PSS) business models and tactics - a systematic literature review. J. Clean. Prod. 97, 61-75.

Remane, G., Hanelt, A., Tesch, J.F., Kolbe, L.M., 2017. The business model pattern database - a tool for systematic business model innovation. Int. J. Innovat. Manag. 21, 1750004, 01 . http://www.worldscientific.com/doi/abs/10.1142 S1363919617500049.

Richardson, J., 2008. The business model: an integrative framework for strategy execution. Strat. Change 17 (5-6), 133-144. https://doi.org/10.1002/jsc.821.

Ritchey, T., 2002. General Morphological Analysis * A General Method for Nonquantified Modelling(revised).

Rizos, V., Behrens, A., Van der Gaast, W., Hofman, E., Ioannou, A., Kafyeke, T. Flamos, A., Rinaldi, R., Papadelis, S., Hirschnitz-Garbers, M., Topi, C., 2016. Implementation of circular economy business models by small and mediumsized enterprises (SMEs): barriers and enablers. Sustainability 8 (11), 1212

Roos, G., 2014. Business model innovation to create and capture resource value in future circular material chains. Resources 3 (1), 248-274. http://www.mdpi. com/2079-9276/3/1/248/.

Rosa, P., Sassanelli, C., Terzi, S., 2019. Towards Circular Business Models: a systematic literature review on classification frameworks and archetypes. J. Clean. Prod. 236, 117696. https://doi.org/10.1016/j.jclepro.2019.117696.

Sauvé, S., Bernard, S., Sloan, P., 2016. Environmental sciences , sustainable development and circular economy : alternative concepts for trans-disciplinary research. Environ. Dev. 17, 48-56. https://doi.org/10.1016/j.envdev.2015.09.002.

Schallmo, D. 2013. Geschäftsmodell-Innovation: Grundlagen, bestehende Ansätze, methodisches Vorgehen und B2B-Geschäftsmodelle. SpringerLink : Bücher. Springer, Wiesbaden. 
Schulte, U.G., 2013. New business models for a radical change in resource efficiency. Environ. Innovat. Soc. Transit. 9, 43-47. https://doi.org/10.1016 j.eist.2013.09.006.

Schwager, P., Moser, F., 2006. The application of chemical leasing business models in Mexico. Environ. Sci. Pollut. Res. Int. 13 (2), 131-137.

Skene, K.R., 2018. Circles, spirals, pyramids and cubes: why the circular economy cannot work. Sustain. Sci. 13, 479-492. https://doi.org/10.1007/s11625-0170443-3.

Slocum, J.W., Mcgill, M., Lei, D.T., 1994. The new learning strategy: anytime, anything, anywhere. Organ. Dynam. 23 (2), 33-47.

Spieth, P., Schneckenberg, D., Ricart, J.E., 2014. Business model innovation - state of the art and future challenges for the field. R D Manag. 44 (3), 237-247.

Stahel, W.R., 1982. The Product Life Factor. An Inquiry into the Nature of Sustainable Societies: the Role of the Private Sector (Series: 1982 Mitchell Prize Papers) NARC.

Stahel, W.R., 2010. The Performance Economy, second ed. Palgrave Macmillan UK London http://link.springer.com/10.1057/9780230274907.

Stahel, W., Reday, G., 1976. The Potential for Substituting Manpower for Energy.

State of Green, 2016. Circular Economy - Denmark as a Circular Economy Solution Hub. www.stateofgreen.com/publications.

Stubbs, W., Cocklin, C., 2008. Conceptualizing a "sustainability business model. Organ. Environ. 21 (2), 103-127. http://journals.sagepub.com/doi/10.1177| 1086026608318042.

Su, B., Heshmati, A., Geng, Y., Yu, X., 2013. A review of the circular economy in China: moving from rhetoric to implementation. J. Clean. Prod. 42, 215-227. https://linkinghub.elsevier.com/retrieve/pii/S0959652612006117.

Tan, A.R., Matzen, D., McAloone, T.C., Evans, S., 2010. Strategies for designing and developing services for manufacturing firms. CIRP J. Manuf. Sci. Technol. 3 (2), 90-97.

Teece, D.J., 2010. Business models, business strategy and innovation. Long. Range Plan. 43 (2-3), 172-194. https://doi.org/10.1016/j.lrp.2009.07.003.

Tirole, J., Jean, T., 1988. The Theory of Industrial Organization. MIT press.

Townsend, M., 2017. Norsk Ombruk AS: the Benefits Case for Remanufacturing.

Tukker, A., 2004. Eight types of product-service system: eight ways for sustainability? Experiences from SUSPRONET. Bus. Strat. Environ. 13, 246-260.

Tukker, A., 2015. Product services for a resource-efficient and circular economy - a review. J. Clean. Prod. 97, 76-91. https://doi.org/10.1016/j.jclepro.2013.11.049.

Türkeli, S., Kemp, R., Huang, B., Bleischwitz, R., McDowall, W., 2018. Circular economy scientific knowledge in the European Union and China: a bibliometric network and survey analysis (2006-2016). J. Clean. Prod. 197, 1244-1261.

Ünal, E. Urbinati, A., Chiaroni, D., Manzini, R., 2019. Value Creation in Circula Business Models: the case of a US small medium enterprise in the building sector. Resour. Conserv. Recycl. 146, 291-307.

Urbinati, A., Chiaroni, D., Chiesa, V., 2017. Towards a new taxonomy of circular economy business models. J. Clean. Prod. 168, 487-498. https://doi.org/10.1016/ j.jclepro.2017.09.047.

van de Velde, D.M., 1999. Organisational forms and entrepreneurship in public transport: classifying organisational forms. Transport Pol. 6 (3), 147-157.

Vasconcelos, L.A., Facin, A.L.F., Salerno, M.S., Ikenami, R.K., 2018. Unpacking the innovation ecosystem construct: evolution, gaps and trends. Technol. Forecast. Soc. Change 136, 30-48.

Velu, C., Stiles, P., 2013. Managing decision-making and cannibalization for parallel business models. Long. Range Plan. 46 (6), 443-458.

Webster, K., 2015. The Circular Economy: A Wealth of Flows. Isle of Wight: Ellen MacArthur Foundation.

WEF, 2014. Towards the Circular Economy: Accelerating the Scale-Up across Global Supply Chains. Cologny. World Economic Forum, Switzerland.

Whalen, K.A., 2019. Three circular business models that extend product value and their contribution to resource efficiency. J. Clean. Prod. 226, 1128-1137. https:// linkinghub.elsevier.com/retrieve/pii/S0959652619308194.

Wirtz, B., Schilke, O., Ullrich, S., 2010. Strategic development of business models: implications of the Web 2.0 for creating value on the internet. Long. Range Plan. 43 (2-3), 272-290.

Wirtz, B.W., Pistoia, A., Ullrich, S., Göttel, V., 2016. Business models: origin, development and future research perspectives. Long. Range Plan. 49 (1), 36-54. http://linkinghub.elsevier.com/retrieve/pii/S0024630115000291.

Wohlin, C., 2014. Guidelines for snowballing in systematic literature studies and a replication in software engineering. In: EASE'14 Proceedings of the 18th International Conference on Evaluation and Assessment in Software Engineering.

Yang, M., Smart, P., Kumar, M., Jolly, M., Evans, S., 2018. Product-service systems business models for circular supply chains. Prod. Plann. Contr. 29 (6), 498-508. https://www.tandfonline.com/doi/full/10.1080/09537287.2018.1449247.

Yuan, Z., Bi, J., Moriguichi, Y., 2008. The circular economy: a new development strategy in China. J. Ind. Ecol. 10 (1-2), 4-8. https://doi.org/10.1162/ 108819806775545321.

Zott, C., Amit, R., Massa, L, 2011. The business model: recent developments and future research. J. Manag. 37 (4), 1019-1042. https://doi.org/10.1177/ 0149206311406265 .

Zotti, J., Bigano, A., 2019. Write circular economy, read economy's circularity. How to avoid going in circles. Econ. Polit. 36, 629-652. https://doi.org/10.1007/s40888019-00145-9.

Zucchella, A., Previtali, P., 2019. Circular business models for sustainable development: a "waste is food" restorative ecosystem. Bus. Strat. Environ. 28 (2), $274-285$. 